\title{
Big Shoes to Fill: CEO Turnover and Pre-Appointment Firm Performance*
}

\author{
Miguel Minutti-Meza \\ MHBS, University of Miami \\ Dhananjay Nanda \\ MHBS, University of Miami \\ Rosy Xu \\ MHBS, University of Miami
}

July 2020

\begin{abstract}
Bayesian learning implies that corporate owners' performance expectations for their CEO are affected by their firm's performance prior to the CEO's appointment because firm asset quality is persistent. Accordingly, we find that the sensitivity of CEO turnover to performance increases in pre-appointment firm performance; that is, a CEO is more likely to be dismissed for underperformance when appointed at a better-performing firm. Consistent with Bayesian learning, we show that this effect increases with firm uncertainty and declines over CEO tenure. We find no evidence that the effect is due to owners' biased assessments of CEO ability or corporate governance quality. Collectively, our results suggest that CEOs, indeed, face a "big shoes to fill" effect that affects their performancerelated turnover likelihood.
\end{abstract}

Keywords: CEO turnover, Bayesian learning, relative performance evaluation, corporate governance.

JEL Codes: G34, J63, M12, M51.

*Minutti-Meza (mminutti@bus.miami.edu), Nanda (d.nanda@miami.edu), and Xu (rxu@bus.miami.edu) are at Miami Herbert Business School, University of Miami, 5250 University Drive, Coral Gables, FL 33146. We appreciate comments and suggestions from Gennaro Bernile, Hemang Desai, and seminar participants at University of Miami Accounting Webinar Series and the 2020 AAA/Deloitte/J. Michael Cook Doctoral Consortium. We thank Dirk Jenter, Florian Peters, and Alexander Wagner for sharing data. We are responsible for all errors and omissions. 


\section{Introduction}

Whether to retain or dismiss a chief executive officer (CEO) is one of the most important decisions corporate owners have to make. Theory and empirical evidence on CEO turnovers suggest that the decision to dismiss the CEO is largely based on poor stock price or accounting performance during an executive's tenure (Coughlan and Schmidt 1985, Warner et al. 1988, Weisbach 1988). The literature on relative performance evaluation (RPE) also suggests that owners filter out industry and market shocks from firm performance in their dismissal decisions (e.g., Jensen and Murphy 1990, Gibbons and Murphy 1990). However, one issue overlooked by prior studies is whether historical firm performance-prior to an executive's appointmentinfluences owners' performance expectations for their CEO and, thereby, affects a CEO's performance-related dismissal likelihood. This issue continues to attract the attention of practitioners and the business press as a "big shoes to fill" phenomenon (Beer 2006, Fowler 2011, Kane 2014, Matthews 2016). ${ }^{1}$ In this paper, we examine whether and how pre-appointment firm performance affects CEO turnover-performance sensitivity.

Following Hermalin and Weisbach (1998), in this study we motivate our analyses using a Bayesian learning model that describes how CEO dismissal decisions are affected by preappointment firm performance. The standard CEO turnover model suggests that owners learn about their CEO's ability from realized firm performance, and dismiss their CEO if performance falls below their expectations. We extend this standard model and posit that historical firm performance not only reflects a prior CEO's ability, but also reveals information about firmspecific fundamental values that persist over time. These fundamental values are related to

\footnotetext{
${ }^{1}$ For example, a Wall Street Journal article (Kane 2014) describes how expectations are set high for Apple's CEO Tim Cook following the superior firm performance led by the former CEO Steve Jobs: "Cook's every decision would be examined by current and former employees and executives, investors, the media and Apple's consumers. He would also have to contend with the sky-high expectations that Jobs had conditioned the public to have for Apple."
} 
factors such as unique physical assets, human capital, systems and processes, products and services, competitive strategies, and market opportunities. Upon observing firm performance prior to a CEO's appointment, owners learn about the quality of their firm's fundamentals and recalibrate their beliefs about future firm performance. For instance, superior pre-appointment performance increases owners' beliefs about firm asset quality, thereby increasing the performance standard for their new CEO. Consequently, higher expectations lead to a greater likelihood that an underperforming $\mathrm{CEO}$ will be dismissed when succeeding a high-performing CEO relative to one with similar performance but following a low-performing CEO. Specifically, the sensitivity of CEO turnover to firm performance increases in pre-appointment firm performance.

We empirically examine this prediction using a sample of 2,073 CEO turnovers and 1,390 performance-induced CEO turnovers among Standard \& Poor's (S\&P) 1,500 firms from 1993 to 2017. We estimate quarterly hazard regressions, wherein the dependent variable is an indicator that equals one if a $\mathrm{CEO}$ is dismissed in the following quarter, and zero otherwise. Our variable of interest is the interaction term between current and pre-appointment firm performance, which we predict is negative. We expect a negative coefficient on our variable of interest because a more negative turnover-performance sensitivity coefficient represents greater sensitivity of CEO turnover to firm performance.

The downward-sloping pattern in Figure 1 illustrates our main finding. The figure plots the CEO turnover-performance sensitivity coefficient over the range of pre-appointment firm performance. The figure demonstrates a strong negative relation: as pre-appointment firm performance increases, the CEO turnover-performance sensitivity coefficient decreases. The interpretation of this finding is that an underperforming CEO is relatively more likely to be 
dismissed when appointed at a firm with superior past performance but less likely to be dismissed when appointed at a firm performing poorly. This suggests that CEOs are not only held accountable for firm performance under their own management but that owners' benchmark for evaluating and dismissing their CEO is also influenced by pre-appointment firm performance. The effect is economically sizable — an increase in pre-appointment firm performance from its 10th to its 90th percentile triples the marginal sensitivity of CEO turnover to firm performance. Our main finding is robust to a battery of tests that explore alternative choices in the estimation model, sample selection, and variable constructions.

We conduct two additional analyses to further explore the Bayesian learning mechanism's implications. First, our framework suggests that belief revisions in light of historical firm performance increase with uncertainty about firm fundamentals. Consequently, we predict that the effect of pre-appointment firm performance on CEO performance-turnover sensitivity increases in firm uncertainty. We examine how our documented relation varies with firm uncertainty by estimating our model within subsamples partitioned on measures of idiosyncratic volatility, firm size, firm age, and analyst forecast dispersion. Consistent with our prediction, we find that the effect of pre-appointment firm performance on CEO performance turnover likelihood is more pronounced in firms with comparatively greater fundamental uncertainty. Visually, this finding manifests as a steeper downward-sloping linear plot of CEO turnoverperformance sensitivity coefficient relative to pre-appointment firm performance with tighter confidence intervals as fundamental uncertainty increases (See Figure 2).

Second, Bayesian learning implies that the weight placed on previously observed signals declines over time as information accumulates (Dikolli et al. 2014, Pan et al. 2015). Therefore, we expect that pre-appointment firm performance becomes less informative over a CEO's tenure 
as more information about their ability accumulates. Consistent with this expectation, we find that the effect of pre-appointment firm performance on CEO turnover-performance sensitivity declines monotonically over a CEO's tenure.

While our results collectively support the Bayesian learning mechanism, we discuss three potential alternative explanations for our main finding. The first concern is that our results are driven by a "contrast effects" bias rather than by Bayesian learning (Kenrick and Gutierrez 1980, Simonsohn and Loewenstein 2006, Bhargava and Fishman 2014, Hartzmark and Shue 2018). This bias implies that owners form biased expectations of CEO ability by contrasting it to their predecessor's competence. For example, owners mistakenly perceived their CEOs as less able than they actually are when they were succeeding a "superstar" CEO; thus, they were more likely to be dismissed (i.e., higher CEO turnover-performance sensitivity). In contrast, Bayesian learning implies that a prior CEO's ability is irrelevant to assessing the ability of an incumbent CEO. Since biased judgments are more likely to be formed when the quality of a subject is uncertain, the "contrast effects" interpretation predicts that the effect of pre-appointment firm performance is more salient when the incumbent CEO's quality is more uncertain (Tverskey and Kahnenman 1974, Hirshleifer 2001). We examine several measures related to CEO ability uncertainty (e.g., CEO age, outsider CEO, and prior experience) and find no evidence that our main finding is driven by a "contrast effects" bias.

The second concern is that our main result is attributable to variation in a firm's corporate governance quality. Corporate governance quality can potentially bias our estimates because it is likely to correlate to both pre-appointment firm performance and CEO turnover-performance sensitivity. For instance, studies have documented that lower CEO turnover-performance sensitivity generally indicates weak corporate governance (Weisbach 1988, Yermack 1996, 
Hermalin and Weisbach 1998, Goyal and Park 2002, Fich and Shivadasani 2006, Knyazeva et al. 2013, Guo and Masulis 2015). It is possible that boards at poorly performing firms are less engaged or are inferior learners about CEO ability than those at well-performing firms, thus allowing untalented CEOs to retain their appointment longer than merited. To alleviate this concern, we include several measures of corporate governance quality commonly used in prior studies (e.g., board independence, board size, busy directors, and CEO-chair duality) as well as their interactions with current firm performance in our main empirical models. We do not find any evidence that our inferences are attributable to variation in corporate governance quality.

We further explore whether the reason behind the prior CEO's turnover affects the relation between pre-appointment firm performance and CEO turnover-performance sensitivity. We estimate our empirical models within two conditions, one in which the predecessor was dismissed due to performance and another in which his departure was non-performance related. We find that the negative relation between pre-appointment firm performance and CEO turnover-performance sensitivity remains economically and statistically significant regardless of the reason for the predecessor CEO's turnover. However, the relation is marginally more pronounced when the predecessor CEO's turnover is performance-induced, likely due to the incremental uncertainty triggered by performance-induced turnovers (Clayton et al. 2005, Taylor 2013).$^{2}$

Our paper makes several significant contributions to the literature. First, it extends the CEO turnover literature by demonstrating that pre-appointment firm performance is an incremental factor in affecting performance expectations for a CEO. Our findings suggest that CEOs have to

2 The "big shoes to fill" phenomenon potentially has implications for CEO compensation. However, our parsimonious framework is limited to examining the relation between performance-induced CEO turnover and preappointment firm performance. To explore CEO compensation effects, one would rely on a more comprehensive model involving negotiations between a manager and the firm, which we consider beyond the scope of our project. 
worry much more about underperforming when appointed at a firm with superior historical performance than when appointed at a firm with bad historical performance. CEOs indeed face a "big shoes to fill" effect that manifests on executives' performance evaluation and turnover likelihood.

Second, our study extends the relative performance evaluation (RPE) literature by investigating how corporate owners form performance expectations for their executives. A large segment of the RPE literature focuses on the assessment of CEO ability by benchmarking firm performance against contemporaneous market or peer performance in setting CEO compensation (Antle and Smith 1986, Gibbons and Murphy 1990, Janakiraman et al. 1992, Hall and Liebman 1998, Aggarwal and Samwick 1999, Rajgopal et al. 2006, Albuquerque 2009) and making CEO dismissal decisions (Coughlan and Schmidt 1985, Warner et al. 1988, Barro and Barro 1990, Jensen and Murphy 1990, Gibbons and Murphy 1990, Murphy and Zimmerman 1993, DeFond and Park 1999). Further, Farrell, and Whidbee (2003) use analysts' forecasts to proxy for performance expectations and find that deviations from analysts' expectations - rather than performance alone - affect the CEO turnover decision. Our findings supplement this inquiry by showing that pre-appointment firm performance provides incremental information; thus, a CEO is also evaluated relative to firm performance preceding his tenure.

Third, our work is related to the extant literature that explains aspects of management incentives and governance decisions using the learning process about management ability (Gibbons and Murphy 1992, Hermalin and Weisbach 1998 2012, Milbourn 2003, Hermalin 2005, Bushman et al. 2010, Taylor 2010 2013, Dikolli et al. 2014, Pan et al. 2015). For instance, Dikolli et al. (2014) show that uncertainty resolution about managerial ability affects the likelihood of a CEO's performance-related dismissal. Our analysis also draws on the asset 
pricing literature that examines the stock market consequences of learning about firms' cashflow generating process (e.g., Timmermann 1993, Pastor and Veronesi 2003). We show that the process of learning about firm fundamentals has significant consequences for CEO dismissal decisions.

The rest of this paper is organized as follows. In Section 2, we provide a parsimonious model to motivate our hypotheses. In Section 3, we describe the data and measures. In Section 4, we present our empirical results. In Section 5, we examine alternative explanations and provide additional analyses. In Section 6, we conclude.

\section{Bayesian Learning and Turnover}

Prior agency theory models suggest that owners evaluate their CEO based on their effort and/or ability (Holmstrom 1979, 1982; Diamond and Verrecchia 1982). Because CEO effort and ability are unobservable, owners use realized observable performance as a noisy measure to infer their CEO's ability. For example,

$$
v=a+\varepsilon,
$$

where $v$ is the performance measure, $a$ is CEO ability, and $\varepsilon$ is a noise term with mean zero. In our paper, we posit that firm performance in time $t, v_{t}$, depends not only on the CEO's timeinvariant ability $\left(a_{i}\right)$ and idiosyncratic noise with mean zero, $\varepsilon_{t}$, but also on an additional factor, $f . f$ is a firm-specific and time-persistent random variable that is also not directly observable to the owner (e.g., the quality of the firm's fundamentals). The presence of $f$ makes $v_{t}$ a noisier signal about CEO ability $\left(a_{i}\right)$ than it would be in the absence of $f$ :

$$
v_{t}=a_{i}+f+\varepsilon_{t} .
$$


Following Hermalin and Weisbach (1998), we assume that a CEO's ability is invariant over his career. After observing firm performance prior to the CEO's appointment $\left(v_{t-1}\right)$, the owner not only infers the previous CEO's ability $\left(a_{j}\right)$, but also learns about the quality of the firm's fundamentals $(f)$. We assume that the prior CEO's ability $\left(a_{j}\right)$, the firm's fundamental value $(f)$ and the firm performance prior to the CEO's appointment $\left(v_{t-1}\right)$ are normally distributed as follows:

$$
\begin{gathered}
a_{j} \sim N\left(\overline{a_{j}}, \tau^{2}\right), \\
f \sim N\left(\bar{f}, \delta^{2}\right), \\
v_{t-1}=a_{j}+f+\varepsilon_{t-1}, \text { with } \varepsilon_{t-1} \sim N\left(0, \sigma^{2}\right),
\end{gathered}
$$

where $\bar{a}_{j}$ and $\tau^{2}$ denote the mean and precision of $a_{j}, \bar{f}$ denotes the mean of the distribution of $f, \delta^{2}$ captures the uncertainty about the firm's fundamental value, and $\varepsilon_{t-1}$ is a noise term with mean zero and variance of $\sigma^{2}$. Although owners cannot directly observe $f$, they update their beliefs about $f$ after observing pre-appointment firm performance $\left(v_{t-1}\right)$ using Bayes rule. As a result, the posterior mean of $f$ (denoted as $m^{\prime}$ ) is a weighted average of the signal $v_{t-1}$ and the prior mean (denoted as $m$ ), with weights inversely proportional to their relative variances:

$$
m^{\prime}=\alpha v_{t-1}+(1-\alpha) m \text {, with } \alpha=\frac{\delta^{2}}{\tau^{2}+\sigma^{2}}
$$

Equation (5) suggests that owners' posterior beliefs about the average quality of the firm's fundamentals $\left(m^{\prime}\right)$ increase with pre-appointment firm performance $\left(v_{t-1}\right)$. The owners subsequently update their expectations for the successor CEO's performance $\left(E\left(v_{t}\right)\right)$ based on their posterior beliefs about the firm's fundamentals $\left(m^{\prime}\right)$ : 


$$
E\left(v_{t}\right)=E\left\{v_{t} \mid v_{t-1}=F\left(m^{\prime}\right)\right\}
$$

The owners dismiss their CEO when their assessment of CEO ability falls below their expectations. Because CEO ability $\left(a_{i}\right)$ is unobservable, owners evaluate their CEO based on firm performance $\left(v_{t}\right)$; for instance, if $v_{t}<E\left(v_{t}\right)$, owners dismiss the CEO. Equation (7) suggests that superior pre-appointment firm performance $\left(v_{t-1}\right)$ increases performance expectations for the CEO, $E\left(v_{t}\right)$. Specifically,

$$
E\left(v_{t} \mid v_{h, t-1}\right)>E\left(v_{t} \mid v_{l, t-1}\right) \text {, if } v_{h, t-1}>v_{l, t-1} .
$$

As a result, firm performance, $v_{t}$, is more likely to fall below expectations at a firm with high pre-appointment performance $\left(v_{h, t-1}\right)$ than at a firm with low performance $\left(v_{l, t-1}\right)$. That dismissal likelihood is a function of performance relative to expectations implies:

$$
\operatorname{Pr}\left\{v_{t}<E\left(v_{t} \mid v_{h, t-1}\right) \mid v_{t}\right\}>\operatorname{Pr}\left\{v_{t}<E\left(v_{t} \mid v_{l, t-1}\right) \mid v_{t}\right\} \text {, if } v_{h, t-1}>v_{l, t-1} \text {. }
$$

Thus, the sensitivity of CEO turnover to firm performance is higher when CEOs are appointed at a firm with high performance $\left(v_{h, t-1}\right)$ than when they are appointed at a firm with low performance $\left(v_{l, t-1}\right)$. Consequently, we hypothesize that:

H1: CEO turnover-performance sensitivity increases in pre-appointment firm performance.

Equation (6) also suggests that pre-appointment firm performance is assigned greater weight if the uncertainty about the firm's fundamental value $\left(\delta^{2}\right)$ is higher. This finding implies that firm performance prior to a CEO's appointment is more informative about the firm's future fundamental values if there is more uncertainty. Hence, we hypothesize that:

H2: The effect of pre-appointment firm performance on CEO turnover-performance sensitivity increases in firm fundamental uncertainty. 


\section{Data and Measures}

\subsection{Sample Selection}

We construct a CEO-firm-quarter data set using the ExecuComp database, which contains information on the top executives of all firms included in the S\&P 1500 index constituents, during the period 1993 to 2017. All accounting information is obtained from the Compustat Fundamental Quarterly file and all stock return data from the Center for Research on Securities Prices (CRSP) daily stock file. Our board characteristics measures are from BoardEx. We obtain analyst forecast data from Institutional Brokers Estimate System (I/B/E/S).

We impose three restrictions on our sample. First, we delete observations with more than one CEO per firm-quarter. Second, for each firm, we require that a CEO must be preceded by another CEO in our dataset. Finally, we exclude observations with missing firm and CEO characteristics after merging the sample with Compustat and CRSP datasets. These criteria yield a final sample of 81,935 observations for 2,122 companies across 25 years. ${ }^{3}$

\subsection{Identifying CEO Turnovers}

We identify CEO turnover based on whether the same individual has the CEO title (i.e., for this individual, the ExecuComp variable ceoann takes the value "CEO") in consecutive quarters. Using precise start (becameceo) and termination (leftofc) dates allows us to identify CEO turnover on a quarterly basis. If the name of the CEO in quarter $t$ is different from the name in quarter $t+1$, we record this as a turnover event in quarter $t$.

We further classify each CEO turnover into performance-induced and non-performanceinduced following Pan et al. (2015). Other studies have also followed this classification

\footnotetext{
${ }^{3}$ In the Internet Appendix Table A1, we estimate our baseline specification in an alternative sample that excludes turnover events possibly involving interim CEOs (with tenure shorter than three years). We obtain materially similar results.
} 
methodology (e.g., Bochkay et al. 2019). CEOs are rarely publicly fired from their positions, and firms usually offer bland, noninformative reasons when announcing CEO departures (e.g., he wants to "spend more time with his family"). We identify turnovers as non-performance-induced if they are caused by death (ExecuComp variable reason is "deceased") or retirement (ExecuComp variable reason is "retired" or variable age is on and above 65) of the departing CEOs. To mitigate the incidence of "suspicious" retirement announcements, we additionally require that the firm's stock performance in the year prior to turnover is above the industry-year median for a turnover reason is "retired." Further, because performance-induced turnovers tend to be preceded by poor firm performance or high stock volatility, we classify turnovers as nonperformance-induced following both good performance (both stock returns and ROA above industry-year median) as well as low idiosyncratic volatility (below industry-year median). All other turnovers are classified as performance-induced.

\subsection{Measuring Firm Performance}

We decompose firm performance into a systematic component related to peer performance and an idiosyncratic component that reflects firm-specific performance. This approach, also known as strong-form relative performance evaluation (RPE), has been previously suggested and widely used in the literature (e.g., Holmstrom and Milgrom 1987, Antle and Smith 1986, Albuquerque 2009, Jenter and Kanaan 2015). The premise is that although firm performance captures CEO ability, it is also affected by components that are beyond a CEO's control, such as industry and economic factors. To conduct an effective assessment, corporate owners benchmark firm performance against the performance of peer firms exposed to common shocks. We obtain the estimated residual from regressing firm performance on peer performance, thereby excluding the component in firm performance related to contemporaneous exogenous factors: 


$$
r_{i, t}=\gamma_{0}+\gamma_{1} * r_{\text {peer group }, t}+v_{i, t}{ }^{4}
$$

Here $r_{i, t}$ is the cumulative stock returns over the current and past three quarters $(t, t-3)$, and $r_{\text {peer group,t }}$ is the equally-weighted cumulative daily stock return over the current and past three quarters $(t, t-3)$ for all firms on CRSP from the same industry as the sample firm, excluding itself. The industry classification follows the Fama and French (1997) classification of firms into 49 industries, with all firms in the "Other" industry excluded. ${ }^{5}$ We use the estimated idiosyncratic component of firm performance $\left(\hat{v}_{i, t}\right)$ as our firm performance measure $\left(P E R F_{i, t}\right)$. We use the $\hat{v}_{i, t}$ in the last quarter of the prior CEO's tenure as the one-year firm performance prior to a CEO's appointment $\left(P A S T_{-} P E R F_{i-1}\right)$. To show that our results are not driven by this choice, in column (1) of Table 4, we use the average idiosyncratic firm performance $\left(\hat{v}_{i, t}\right)$ over the entire tenure of the prior CEO's appointment. Our findings are unaffected.

\subsection{Measuring Firm and CEO Characteristics}

We also use a set of standard firm and CEO characteristics as covariates in our estimations to account for factors that potentially affect CEO turnovers. We include three firm characteristics: firm size $\left(S I Z E_{i, t}\right)$, measured as the log of total book assets at the end of the fiscal quarter, since firm size is likely correlated with the CEO turnover likelihood (Dikolli et al. 2013); stock return volatility $\left(V O L_{i, t}\right)$, measured as the standard deviation of a firm's monthly stock returns over the

\footnotetext{
${ }^{4}$ An important choice in the empirical design is whether to allow the sensitivity of firm performance to peer performance to differ across CEO-firm pairs. Estimating CEO-firm-specific $\gamma_{1}$ introduces additional estimation error into the residual. To avoid this problem, and to be consistent with the prior literature, we estimate a common peer performance $\gamma_{1}$ for all firms. In the Internet Appendix Table A2, we repeat the estimation with CEO-firmspecific $\gamma_{1}$ and firm-specific $\gamma_{1}$, we obtain similar results.

${ }^{5}$ One challenge for empirical researchers is to identify appropriate peer firms that corporate owners uses to benchmark performance (Albuquerque 2009). Since 2006, the U.S. Security and Exchange Commission (SEC) has required all public firms to disclose the peer group(s) that they use to either set managerial compensation (compensation peers) or evaluate management's relative performance (RPE peers), as long as the use of a peer group is material. Based on proxy statements of S\&P 1500 firms from 2006 to 2010, Francis et al. (2016) find that industry plays the most prominent role in RPE peer selection and the majority $(75 \%)$ of disclosed RPE peers share the same Fama-French industry as the reporting firm.
} 
prior 36 months, aggregated annually, since performance-measure variability is inversely related to the performance-related turnover likelihood (Engel et al. 2003); book-to-market ratio $\left(B T M_{i, t}\right)$, measured as market value divided by book value of equity at the end of the fiscal quarter, since firm growth opportunities are associated with the likelihood of CEO turnovers (DeFond and Park 1999). We further include two CEO characteristics that are associated with the turnover likelihood: $L O G A G E_{i, t}$, measured as the natural logarithm of CEO age in years; and, RETIREMENT $T_{i, t}$, an indicator variable that equals one if CEO age is between and including ages 63 and 66, and zero otherwise (Murphy 1999).

\subsection{Summary Statistics}

Table 1 describes our data. Panel A reports the frequencies of turnovers and performanceinduced turnovers. Our sample has 2,122 firms with 81,935 firm-quarter observations from 1993 to 2017 and consists of 2,073 turnovers, of which 1,390 turnovers are classified as performanceinduced.

Panel B shows firm and CEO characteristics by CEO retention outcome (CEO is retained, CEO is dismissed due to performance-related reasons, and CEO leaves for non-performancerelated reasons). Firms with CEO turnovers due to performance issues are smaller, undervalued, with more volatile stock returns, and with worse financial and accounting performance than firms with non-performance-induced turnovers. This difference is due to the fact that CEO dismissals are preceded by poor and volatile performance and associated declines in firm size. We also find that dismissed CEOs are on average younger and have shorter tenures than CEOs who leave for reasons unrelated to firm performance. 


\section{Bayesian Learning and CEO Turnovers}

\subsection{Effect of Pre-Appointment Firm Performance on CEO Turnover-Performance Sensitivity}

We examine whether and how firm performance prior to a CEO's appointment affects their turnover-performance sensitivity by interacting current firm performance $\left(P E R F_{i, t}\right)$ with preappointment firm performance (PAST_PERF $\left.F_{i-1}\right)$ using the Cox (1972) proportional hazard model. The Cox hazard model estimates the likelihood that a CEO will retain office until a certain point in time (i.e., quarter $t$ ) based on the CEO's survival in earlier periods. The hazard model flexibly accommodates the fact that each CEO's hazard rate, that is, the probability that a CEO is dismissed over the next quarter, is a function of that CEO's tenure as well as other firm and CEO characteristics. We treat non-performance-induced turnovers as right-censored observations in our estimation. Specifically, we estimate the following model:

$$
\begin{aligned}
& \text { Probability }\left(\text { TURNOVER } R_{i, t} \text { or PERF_TURNOVER } R_{i, t}\right)=\beta_{0}+\beta_{1} P E R F_{i, t}+ \\
& \beta_{2} P A S T_{-} P E R F_{i-1}+\beta_{3} P E R F_{i, t} \times P A S T_{-} P E R F_{i-1}+ \\
& \text { Firm and CEO } \text { characteristics }_{i, t}+\text { YearQuarterFE }+\varepsilon_{i, t},(11)
\end{aligned}
$$

where the subscript $t$ indicates time in quarters, and the subscript $i$ indicates a CEO-firm pair. The dependent variable is either TURNOVER $R_{i, t}$ or PERF_TURNOVER ${ }_{i, t .}$ TURNOVER $R_{i, t}$ is an indicator variable that equals one if the incumbent CEO leaves office in quarter $t+1$, and zero otherwise. PERF_TURNOVER $R_{i, t}$ is an indicator variable that equals one if the incumbent $\mathrm{CEO}$ is dismissed due to performance-related reasons in quarter $t+1$, and zero otherwise. The performance-induced turnover classification follows Pan et al. (2015) and is discussed in detail in Section 3.2. Our coefficient of interest is $\beta_{3}$, which reflects the incremental effect of preappointment firm performance on CEO turnover-performance sensitivity. Our model includes 
year-quarter fixed effects to account for likely time trends in the dependent variable. ${ }^{6}$ We cluster standard errors at the firm level.

We predict that the coefficient on the interaction term $\left(P E R F_{i, t} \times P A S T_{-} P E R F_{i-1}\right)$ is negative because owners' expectations about the firm's future performance are heightened following superior performance under the prior CEO's management, thereby increasing the sensitivity of an incumbent CEO's turnover to firm performance. A more negative turnover-performance sensitivity coefficient represents a greater sensitivity of CEO turnover to firm performance.

There are important differences between including pre-appointment firm performance as another linear covariate and including the variable and also its interaction with current performance (i.e., a non-linear model). Under the latter, the marginal effect of current performance depends on the value of pre-appointment performance. The differences can be illustrated by taking the partial derivative of the two models with respect to current performance. In the linear model $\triangle T U R N O V E R_{i, t} / \triangle P E R F_{i, t}=\beta_{1}$, while in the non-linear model $\triangle T U R N O V E R_{i, t} / \triangle P E R F_{i, t}=\beta_{1}+\beta_{3} P A S T_{-} P E R F_{i-1}$. We use the second specification in our analyses. Finally, our focus on the interaction makes our inferences only conditional on historical firm performance.

Panel A of Table 2 tabulates our results. ${ }^{7}$ Columns (1) and (2) display results from estimating Equation (11) using turnover events without any classification. In column (1), we

\footnotetext{
${ }^{6}$ In column (1) of Internet Appendix Table A3, we show that our results are robust to including industry fixed effects. However, adding too many fixed effects in a non-linear model can cause the incidental parameters problem (Neyman and Scott 1948). We therefore intentionally do not include industry fixed effects in our baseline specification. In column (2), we additionally use hazard regression with stratification by allowing baseline hazards (the hazard rates when subjects enter the study) to be different across year-quarters and industries to account for likely time trends and industry patterns in the dependent variable. We obtain materially similar results.

${ }^{7}$ In untabulated robustness tests, we adopt a parsimonious model without fixed effects or covariates of firm and CEO characteristics. We find that the coefficient estimate of PERF $F_{i, t} \times P A S T$ PERF $F_{i-1}$ is -0.551 ( $p$-value $\left.<0.01\right)$ when the dependent variable is TURNOVER $R_{i, t}$ and -0.837 ( $p$-value $\left.<0.0 \overline{1}\right)$ when the dependent variable is
} 
obtain a statistically significant coefficient on $P E R F_{i, t} \times P A S T_{-} P E R F_{i-1}$ of -0.516 ( $p$-value $<$ 0.01). This negative and significant coefficient suggests that a CEO's performance-turnover sensitivity is increasing in firm performance before the appointment. Because turnovers are more likely to follow poor performance, especially in performance-induced cases, we follow Dikolli et al. (2014) and separately include the positive $\left(P O S_{-} P E R F_{i, t}\right)$ and negative $\left(N E G_{-} P E R F_{i, t}\right)$ components of current firm performance and their interactions with $P A S T_{-} P E R F_{i-1}$ in column (2). POS_PERF $F_{i, t}\left(N E G_{-} P E R F_{i, t}\right)$ is equal to the value of $P E R F_{i, t}$ if $P E R F_{i, t}$ is positive (negative), and zero otherwise. We find that the coefficient on $N E G_{-} P E R F_{i, t} \times P A S T_{-} P E R F_{i-1}$ is negative and statistically significant at the $1 \%$ level. The coefficient on POS_PERF $F_{i, t} \times P A S T_{-} P E R F_{i-1}$ is statistically insignificantly different from zero. The fact that the effect of pre-appointment firm performance is only significant when the incumbent CEO is underperforming suggests that preappointment firm performance affects owners' CEO dismissal decisions.

Columns (3) and (4) tabulate results from estimating Equation (11) using performanceinduced turnover events. In column (3), we continue to find a negative and statistically significant coefficient of interest of -0.770 ( $p$-value $<0.01$ ). Column (4) again suggests that the effect of pre-appointment firm performance is more pronounced when an incumbent CEO is underperforming. We also observe that the coefficient magnitudes for $P E R F_{i, t}$ and $P E R F_{i, t} \times$ PAST_PERF $F_{i-1}$ are substantially larger when using PERF_TURNOVER $R_{i, t}$ rather than TURNOVER ${ }_{i, t}$ as the dependent variable. This suggests that the turnover classification, as in Pan et al. (2015), largely filters out turnovers that are not performance-related. In the remainder of the paper, unless otherwise noted, we use PERF_TURNOVER $R_{i, t}$ as our main dependent variable, and refer to column (3) of Table 2, Panel A as our baseline specification.

PERF_TURNOVER $R_{i, t}$, suggesting a negative raw association between pre-appointment firm performance and CEO turnover-performance sensitivity. 
Instead of Cox hazard regressions, prior literature also uses logit regressions to examine performance-related CEO turnover. To examine that our results are not an artifact of using the (arguably more suitable) hazard model, we repeat our analysis using a logit model in Panel B. Since the logit model by itself does not account for the effect of tenure on the likelihood of CEO dismissals, we include CEO tenure in months as a covariate. We present our results in Panel B. ${ }^{8}$ Figure 1 shows the graphical analog to the regression result in column (3) of Table2, Panel B. The graph shows that the sensitivity coefficient in a CEO turnover model is inversely related to pre-appointment firm performance, indicating that the likelihood that a CEO is dismissed for poor performance increases in pre-appointment firm performance.

The effect of pre-appointment firm performance on CEO turnover-performance sensitivity is economically large. Table 3 presents the marginal sensitivity of firm performance on performance-induced turnovers estimated at different percentiles of pre-appointment firm performance derived from the logit model in column (3) of Table 2, Panel B. The marginal sensitivity of PERF $i, t$ on PERF_TURNOVER $R_{i, t}$ is -0.564 at the 90th percentile value of PAST_PERF $F_{i-1}$, whereas it is -0.180 at the 10 th percentile. Consequently, an increase in preappointment firm performance from the 10th percentile to the 90th percentile increases the marginal performance-related turnover sensitivity threefold.

Finally, we examine whether our main finding is robust to alternative choices in measure construction. Table 4 presents our results. First, to show that our results are not driven by the

\footnotetext{
${ }^{8} \mathrm{Ai}$ and Norton (2003) shows that researchers can draw erroneous conclusions about the sign and the significance of the interaction term in nonlinear models by examining the coefficient on the interaction term. To ensure that we draw valid inferences on the interaction variable effect, we plot the marginal effect of the interaction variable $\left(P E R F_{i, t} \times\right.$ PAST_PERF $\left.F_{i-1}\right)$ using the delta method described by Ai and Norton (2003) in the Internet Appendix Figure A1. We find negative marginal interaction effect across different levels of predicted performance-induced turnover probability. We therefore conclude that the corrected marginal interaction effect generated from $\mathrm{Ai}$ and Norton (2003) is consistent and very similar to the marginal interaction effect using the logit model.
} 
arbitrary time window that we use to measure pre-appointment firm performance, in column (1), we use the average idiosyncratic stock return over the previous CEO's entire tenure $\left(P A S T \_P E R F \_T E N U R E_{i-1}\right)$. The result suggests that the specific time window that we choose to measure pre-appointment firm performance in our baseline specification does not account for our results.

Second, we examine robustness to alternative measures of firm performance. Prior research argues that stock returns reflect the market's expectations regarding future value and therefore are less useful in assessing current managerial performance (Hermalin and Weisbach 1998, Engel et al. 2003). ${ }^{9}$ In column (2), we show that our main finding is robust to using operating performance (i.e., ROA). Further, our main analysis measures firm performance using a strongform relative performance evaluation approach. This strong-form approach assumes complete peer performance filtering from CEO evaluation. To show that our results do not rely on this strong assumption, we explore various alternative firm performance measures. In columns (3) to (5), we measure firm performance using four-quarter cumulative stock returns, industry-mean adjusted four-quarter cumulative stock returns, and strong-form relative performance evaluation with value-weighted peer performance. We find statistically significant and negative interaction effects in all specifications, and we conclude that alternative measures of firm performance do not qualitatively change our previously reported estimates.

Third, we examine robustness to alternative CEO turnover classifications. In column (6), we adopt a machine-based approach to classify turnovers into performance-related and non-

\footnotetext{
${ }^{9}$ Despite the argument, our choice of stock returns to evaluate CEO performance is for at least two reasons. First, $74 \%$ of S\&P 1500 firms rely on stock returns in evaluating executive performance, based on the first proxy statements under the new executive compensation disclosure regime in 2006 (Gong et al. 2011). Second, although stock returns may not always be the measure that corporate owners use in evaluating CEO performance, they are sufficiently correlated with the measures that are used to evaluate managers (Warner et al. 1998).
} 
performance-related proposed by Jenter and Lewellen (2020). ${ }^{10}$ In column (7), we classify turnovers into forced and voluntary using press reports along with an age criterion and further refinements following Parrino (1997), Peters and Wagner (2014), and Jenter and Kanaan (2015). ${ }^{11}$ We again find a significant negative relation.

\subsection{Effect of Uncertainty about Firm Fundamentals}

Our Bayesian learning model in section 2 additionally suggests that when uncertainty about the firm's fundamental value is higher, observable signals, such as pre-appointment firm performance, lead to larger belief revisions. Consequently, we predict that the effect of preappointment firm performance on CEO performance-turnover sensitivity increases in firm uncertainty. We test this prediction by performing cross-sectional analyses, partitioning our sample on four measures of a firm's fundamental uncertainty. Although each potentially captures other factors, the common element is their ability to reflect uncertainty about the firm's fundamental value.

Our first measure for a firm's fundamental uncertainty is Idiosyncratic Volatility, which is measured as the volatility of residual daily stock return from the Fama-French three-factor model, aggregated at the quarterly level. Columns (1) and (2) in Table 5 present our results. We rank all CEO-firm pairs by the average idiosyncratic volatility over the last four quarters prior to CEO appointment and classify the low (high) group as those whose idiosyncratic volatility is less (greater) than the bottom (top) tercile of the idiosyncratic volatility distribution. We find a

\footnotetext{
${ }^{10}$ Performance-induced turnovers are defined as those that would not have occurred had performance been "good". Intuitively, turnovers at a sufficiently high-performance level, such as the 90th percentile of the performance distribution, are assumed to be unrelated to performance and would have occurred regardless of performance. As a result, any higher turnover rate at lower performance levels is assumed to be caused by performance being worse. These additional turnovers are labeled as performance induced.

${ }^{11}$ We are grateful to Dirk Jenter, Florian Peters, and Alexander Wagner for sharing the data from Peters and Wagner (2014) and Jenter and Kahaan (2015) regarding whether or not a CEO was forced out or left firm voluntarily.
} 
negative and statistically significant relation between pre-appointment firm performance and CEO turnover-performance sensitivity among CEO-firm pairs with high idiosyncratic volatility (coefficient $=-0.636, z$-statistics $=-3.119)$, but not among those with low idiosyncratic volatility (coefficient $=-0.259, z$-statistics $=-0.448$ ). This result suggests that learning is more pronounced when uncertainty about the firm's fundamentals is higher.

Our second measure is Firm Size (e.g., Zhang 2006), measured as the natural logarithm of the book value of assets. It seems plausible that smaller firms are less diversified, and therefore their underlying fundamental volatility is higher. ${ }^{12}$ Columns (3) and (4) in Table 6 present our results. We rank all CEO-firm pairs by the average firm size over the last four quarters prior to the CEO's appointment and partition our sample into low and high groups based on the bottom and top firm size terciles. We find that the effect of pre-appointment firm performance is more salient among smaller firms (coefficient $=-0.953, z$-statistics $=-4.663$ ) than larger firms (coefficient $=-0.653, z$-statistics $=-1.362$ ). This result also supports our prediction.

Our third measure is Firm Age (e.g., Zhang 2006), measured as the number of years since the firm was first covered by the CRSP database. Since firms with longer history have a larger information set, there is less uncertainty regarding their fundamental values. Columns (5) and (6) tabulate our results. We rank all CEO-firm pairs by firm age in the quarter prior to a CEO's appointment and sort CEO-firm pairs into low and high groups if firm age is in the bottom and top terciles of the firm age distribution. We find that the effect of pre-appointment firm performance on CEO turnover-performance sensitivity is significant among young firms

\footnotetext{
${ }^{12}$ Previous literature also uses firm size to proxy for information uncertainty stemming from poor information quality (Zhang, 2006). For example, small firms may have fewer customers, suppliers, and shareholders, and may not bear high disclosure costs. Investors might have fixed costs of information acquisition, which makes small firms' stocks unattractive. However, such uncertainty from poor information quality is not the type of uncertainty we discussed here.
} 
(coefficient $=-0.710, z$-statistics $=-3.190$ ). However, for older firms, the effect of preappointment firm performance is statistically insignificant (coefficient $=-0.604, z$-statistics $=-$ 1.459).

Our last uncertainty measure is Analyst Forecast Dispersion (e.g., Imhoff and Lobo 1992, Barron et al. 1998, Barron and Shuerke 1998, Zhang 2006), which is measured as the standard deviation of analyst quarterly earnings forecasts, scaled by the stock price 30 trading days prior to the quarterly earnings announcement. We tabulate our results in columns (7) and (8). We rank all CEO-firm pairs by the average analyst forecast dispersion over the four quarters prior to a CEO's appointment and sort CEO-firm pairs into low and high groups using the same categorization approach. The evidence is consistent with our prediction: we find a negative and statistically significant relation in the subsample with high analyst forecast dispersion (coefficient $=-0.783, z$-statistics $=-3.233$ ). For subsample with low analyst forecast dispersion, the effect of pre-appointment firm performance is insignificant (coefficient $=-0.115, z$-statistics $=-0.373)$.

Overall, consistent with the Bayesian learning mechanism, we find that the effect of preappointment firm performance on CEO turnover-performance sensitivity is more pronounced among firms with greater uncertainty (i.e., more volatile, smaller, younger, and with higher analyst forecast dispersion). Visually, this manifests as a steeper downward-sloping linear plot of CEO turnover-performance sensitivity coefficient relative to pre-appointment firm performance with tighter confidence intervals when firm fundamental uncertainty is higher (See Figure 2).

\subsection{Effect of Pre-Appointment Firm Performance over a CEO's Tenure}

We further explore how the relation between pre-appointment firm performance and CEO turnover-performance sensitivity changes over a CEO's tenure. Prior work on Bayesian learning 
suggests that the weight placed on a previously observed signal declines over time as more current information accumulates (Dikolli et al. 2014, Pan et al. 2015). Therefore, we predict that pre-appointment firm performance should become less informative over a CEO's tenure since more information about the firm's fundamental value accumulates over the CEO's career.

In table 6, we split our sample into those CEOs with at least one year, two years, three years, and more than three years since they take office and re-estimate our baseline specification within each subsample. We find that the effect of pre-appointment firm performance monotonically decline over a CEO's tenure. Specifically, the coefficient on our variable of interest $\left(P E R F_{i, t} \times\right.$ PAST_PERF $\left.F_{i-1}\right)$ increases from -0.770 in the first year of the CEO's tenure to -0.636 in the second year, -0.460 in the third year, and an insignificant -0.309 in the fourth year or later. The monotonic increase in the coefficient of interest is consistent with a diminishing learning effect of pre-appointment firm performance on owners' performance expectation revisions.

\section{Alternative Explanations}

\subsection{Biased Assessment of CEO Ability}

While our results are consistent with the Bayesian learning mechanisms predictions, we discuss two potential alternative explanations. The first is that owners form a biased assessment of an incumbent CEO's ability by contrasting it with the predecessor CEO's ability, i.e., "contrast effects" bias. A "contrast effects" bias arises when the value of a previously observed signal inversely biases the perception of the next signal. "Contrast effects" have the potential to bias a wide variety of real-world decisions, e.g., judicial judgment (Kenrick and Gutierres 1980), housing selection (Simonsohn and Loewenstein 2006), mate choice (Bhargava and Fisman 2014), and investors' reaction to earnings news (Hartzmark and Shue 2019). In our context, owners can mistakenly perceive their CEO's ability as lower than true ability by contrasting it with the 
superior ability of a predecessor CEO. Similarly, owners can biasedly believe that the CEO's ability is higher by juxtaposing against an unsuccessful former CEO. Therefore, the negative relation between pre-appointment firm performance and CEO turnover-performance sensitivity can be potentially driven by contrast effects.

Research on cognitive biases suggests that biased judgments are more likely formed when the quality of a subject is uncertain (e.g., Tverskey and Kahnenman 1974, Hirshleifer 2001). Therefore, the "contrast effects" hypothesis predicts that the effect of pre-appointment firm performance on CEO turnover-performance sensitivity should be stronger among firms with greater uncertainty about their incumbent CEOs' ability. Following prior literature (Pan et al. 2015, Bochkay et al. 2019), we use three measures to proxy for CEO ability uncertainty: CEO Age, Outsider CEO, and Prior Experience. Younger CEOs have shorter track records and less visibility than older CEOs, and thus their ability is more uncertain relative to their older counterparts. In addition, we expect that an outsider CEO's ability uncertainty is higher than an insider CEO's because of the larger unknown match quality between an outsider and the firm. Finally, uncertainty about ability is also likely to be inversely related to CEO experience, measured as the number of prior executive positions held before a CEO appointment. We construct these variables using data on job title and CEO age from ExecuComp and on prior managerial experience from BoardEx.

Table 7, Panel A presents our results. In columns (1) and (2), we partition our sample into low and high groups based on the bottom and top terciles of the distribution of CEO Age when a CEO assumes office. We find the negative and statistically significant relation between preappointment firm performance and CEO turnover-performance sensitivity persists among old CEOs but not among young CEOs, which contradicts the prediction from a "contrast effect" 
hypothesis. Columns (3) and (4) show our cross-sectional results based on whether the incumbent CEO is an outsider or not. We find the previously documented effect persists in both subsamples. In columns (5) and (6), we split the sample based on the distribution of Prior Experience and find similar results in both subsamples. Collectively, our results are inconsistent with the effect of pre-appointment firm performance on CEO turnover-performance sensitivity being driven by cognitive biases.

\subsection{Quality of Corporate Governance}

The second alternative explanation is that our result is potentially driven by the quality of corporate governance. Corporate governance quality can potentially bias our estimates because it is likely correlated with both pre-appointment firm performance and CEO turnover-performance sensitivity. Prior research finds that a decrease in the performance sensitivity of turnover generally coincides with weak monitoring, for example, in situations where a board is dominated by outsiders (Weisbach 1988, Hermalin and Weisbach 1998, Knyazeva et al. 2013, Guo and Masulis 2015), the board is large (Yermack 1996), the majority of the directors are busy (Fich and Shivadasani 2006), or the CEO also serves as board chair (Goyal and Park 2002). It is possible that boards at poorly performing firms are slower learners of their CEOs' ability than those at high-performing firms, thus allowing untalented CEOs to retain their appointments regardless of performance. Also, a CEO is likely more entrenched in a poorly-performing firm, and as a result, firing the CEO entails a significant personal cost to the board. The personal cost arises from the board with personal or professional ties to the $\mathrm{CEO}$, or because firing the CEO puts the directors' jobs at risk, requires uncompensated effort, or hurts directors' chances of being nominated to other boards (Hermalin and Weisbach 1998). 
To alleviate this concern, we re-estimate our baseline specification and include several measures related to governance quality as covariates, as well as their interactions with current firm performance. If the effects that we attribute to pre-appointment firm performance are in fact caused by the quality of corporate governance, the coefficient on our variable of interest $\left(P E R F_{i, t}\right.$ $\times$ PAST_PERF $i-1)$ should lose significance.

Following prior literature, we employ four measures of corporate governance quality that have received attention in the literature: INDEPENDENCE $E_{i, t}$, measured as the percentage of independent directors; BOARDSIZE $E_{i, t}$, measured as the natural logarithm of the number of directors; $B U S Y B O A R D_{i, t}$, measured as the number of independent directors who serve on three or more boards, scaled by the total number of independent directors; and DUALITY, $Y_{i, t}$ an indicator variable that equals one when the CEO also serves as board chair, zero otherwise. Table 7, Panel B reports estimates from regressions that include each measure and its interaction with current firm performance. One important implication from the regression estimates is that the coefficients associated with pre-appointment firm performance do not significantly change when the corporate governance measures are included. Specifically, the key interaction coefficient remains negative and statistically significant in every specification. Overall, our

results provide no evidence that the observed "big shoes to fill" phenomenon is driven by variations in corporate governance quality.

\subsection{Reasons for the Predecessor CEO's Turnover}

We examine whether the reason for the prior CEO's departure affects our documented relation between pre-appointment firm performance and CEO turnover-performance sensitivity. We partition our sample based on whether the departure of the prior CEO was performanceinduced or non-performance-induced and repeat our baseline estimation within each subsample. 
Table 8 presents our results. We find the negative and statistically significant relation between pre-appointment firm performance and CEO turnover-performance sensitivity in both subsamples. The result suggests that the effect of pre-appointment firm performance on CEO turnover-performance sensitivity is unaffected by the reason for a predecessor's turnover. Further, we find that the impact of pre-appointment firm performance is slightly stronger when a predecessor departed due to underperformance rather than other reasons. This result supports our Bayesian learning mechanism that owners learn more about the firm's fundamental value in times of high fundamental uncertainty triggered by predecessor CEO's performance-induced leave (Clayton et al. 2005, Taylor 2013).

\section{Conclusion}

A key aspect of firm corporate governance is the corporate owners' decision to retain or fire the CEO. We add to our understanding of CEO dismissal decisions by examining whether and how firm performance prior to a CEO appointment affects their performance-turnover likelihood. We use a quarter-century sample of CEO turnovers among S\&P 1500 firms and document a "big shoes to fill” phenomenon in CEO turnovers. Specifically, as pre-appointment firm performance increases, the CEO turnover-performance sensitivity coefficient decreases, suggesting that an underperforming CEO is more likely to be dismissed if appointed at a firm with superior performance. Overall, our results suggest that CEOs are evaluated on their firm's performance in light of historical firm performance prior to their appointment.

We rely on a Bayesian learning model to motivate our inquiry: corporate owners update performance expectations for their CEOs based on what they learn about the firm's fundamental values from the pre-appointment firm performance. Next, consistent with this learning mechanism, we find that the effect of pre-appointment firm performance is more pronounced for 
firms with relatively higher uncertainty (i.e., more volatile, smaller, younger, and with higher analyst forecast dispersion). Finally, we find that the effect of pre-appointment firm performance declines monotonically over a CEO's tenure, supporting the idea of Bayesian learning.

Our results have significant contributions to the literature. First, our paper furthers our understanding of CEO dismissal decisions by highlighting that turnover is not only related to firm performance under an incumbent's direction but also affected by the performance before he assumes office. Second, while the RPE literature largely focuses on the relative assessment of CEO quality to contemporaneous peers, our paper extends this inquiry by showing that corporate owners form performance expectations for their executives based on their predecessor's performance. Third, our work draws on the literature that explains aspects of management incentives and governance decisions using the learning process about management ability. Our study shows that learning about a firm's fundamental value is consequential for CEO dismissal decisions. 


\section{References}

Aggarwal, R.K. and Samwick, A.A., 1999. Executive compensation, strategic competition, and relative performance evaluation: Theory and evidence. The Journal of Finance, 54(6), pp.19992043.

Ai, C. and Norton, E.C., 2003. Interaction terms in logit and probit models. Economics Letters, 80(1), pp.123-129.

Albuquerque, A., 2009. Peer firms in relative performance evaluation. Journal of Accounting and Economics, 48(1), pp.69-89.

Albuquerque, A.M., De Franco, G. and Verdi, R.S., 2013. Peer choice in CEO compensation. Journal of Financial Economics, 108(1), pp.160-181.

Antle, R. and Smith, A., 1986. An empirical investigation of the relative performance evaluation of corporate executives. Journal of Accounting Research, pp.1-39.

Barro, J.R. and Barro, R.J., 1990. Pay, performance, and turnover of bank CEOs. Journal of Labor Economics, 8(4), pp.448-481.

Barron, O.E., Kim, O., Lim, S.C. and Stevens, D.E., 1998. Using analysts' forecasts to measure properties of analysts' information environment. The Accounting Review, pp.421-433.

Barron, O.E. and Stuerke, P.S., 1998. Dispersion in analysts' earnings forecasts as a measure of uncertainty. Journal of Accounting, Auditing \& Finance, 13(3), pp.245-270.

Beer, M., 2006. Big shoes to fill. Harvard Business Review, 84(5), p.43.

Bochkay, K., Chychyla, R. and Nanda, D., 2019. Dynamics of CEO disclosure style. The Accounting Review, 94(4), pp.103-140.

Bushman, R., Dai, Z. and Wang, X., 2010. Risk and CEO turnover. Journal of Financial Economics, 96(3), pp.381-398.

Clayton, M.C., Hartzell, J.C. and Rosenberg, J., 2005. The impact of CEO turnover on equity volatility. The Journal of Business, 78(5), pp.1779-1808.

Coughlan, A.T. and Schmidt, R.M., 1985. Executive compensation, management turnover, and firm performance: An empirical investigation. Journal of Accounting and Economics, 7(1-3), pp.43-66.

Cox, D.R., 1972. Regression models and life-tables. Journal of the Royal Statistical Society: Series B (Methodological), 34(2), pp.187-202. 
DeFond, M.L. and Park, C.W., 1999. The effect of competition on CEO turnover. Journal of Accounting and Economics, 27(1), pp.35-56.

Diamond, D.W. and Verrecchia, R.E., 1982. Optimal managerial contracts and equilibrium security prices. The Journal of Finance, 37(2), pp.275-287.

Dikolli, S.S., Mayew, W.J. and Nanda, D., 2014. CEO tenure and the performance-turnover relation. Review of Accounting Studies, 19(1), pp.281-327.

Engel, E., Hayes, R.M. and Wang, X., 2003. CEO turnover and properties of accounting information. Journal of Accounting and Economics, 36(1-3), pp.197-226.

Fama, E.F. and French, K.R., 1997. Industry costs of equity. Journal of Financial Economics, 43(2), pp.153-193.

Farrell, K.A. and Whidbee, D.A., 2003. Impact of firm performance expectations on CEO turnover and replacement decisions. Journal of Accounting and Economics, 36(1-3), pp.165-196.

Fich, E.M. and Shivdasani, A., 2006. Are busy directors effective monitors? The Journal of Finance, 61(2), pp.689-724.

Fowler, G.A.,2011. Apple's new CEO Tim Cook has big shoes to fill. The Wall Street Journal, October 6.

Francis, B., Hasan, I., Mani, S. and Ye, P., 2016. Relative peer quality and firm performance. Journal of Financial Economics, 122(1), pp.196-219.

Gibbons, R. and Murphy, K.J., 1990. Relative performance evaluation for chief executive officers. Industrial and Labor Relations Review, 43(3), pp.30-S.

Gibbons, R. and Murphy, K.J., 1992. Optimal incentive contracts in the presence of career concerns: Theory and evidence. Journal of Political Economy, 100(3), pp.468-505.

Gong, G., Li, L.Y. and Shin, J.Y., 2011. Relative performance evaluation and related peer groups in executive compensation contracts. The Accounting Review, 86(3), pp.1007-1043.

Goyal, V.K. and Park, C.W., 2002. Board leadership structure and CEO turnover. Journal of Corporate Finance, 8(1), pp.49-66.

Guo, L. and Masulis, R.W., 2015. Board structure and monitoring: New evidence from CEO turnovers. The Review of Financial Studies, 28(10), pp.2770-2811.

Hall, B.J. and Liebman, J.B., 1998. Are CEOs really paid like bureaucrats? The Quarterly Journal of Economics, 113(3), pp.653-691. 
Hartzmark, S.M. and Shue, K., 2018. A tough act to follow: Contrast effects in financial markets. The Journal of Finance, 73(4), pp.1567-1613.

Hermalin, B.E., 2005. Trends in corporate governance. The Journal of Finance, 60(5), pp.23512384.

Hermalin, B.E. and Weisbach, M.S., 1998. Endogenously chosen boards of directors and their monitoring of the CEO. American Economic Review, pp.96-118.

Hermalin, B.E. and Weisbach, M.S., 2012. Information disclosure and corporate governance. The Journal of Finance, 67(1), pp.195-233.

Hirshleifer, D., 2001. Investor psychology and asset pricing. The Journal of Finance, 56(4), pp.1533-1597.

Holmstrom, B., 1979. Moral hazard and observability. The Bell Journal of Economics, 10(1), pp.74-91.

Holmstrom, B., 1982. Moral hazard in teams. The Bell Journal of Economics, pp.324-340.

Imhoff Jr, E.A. and Lobo, G.J., 1992. The effect of ex ante earnings uncertainty on earnings response coefficients. The Accounting Review, pp.427-439.

Janakiraman, S.N., Lambert, R.A. and Larcker, D.F., 1992. An empirical investigation of the relative performance evaluation hypothesis. Journal of Accounting Research, 30(1), pp.53-69.

Jensen, M.C. and Murphy, K.J., 1990. Performance pay and top-management incentives. Journal of Political Economy, 98(2), pp.225-264.

Jenter, D. and Kanaan, F., 2015. CEO turnover and relative performance evaluation. The Journal of Finance, 70(5), pp.2155-2184.

Jenter, D. and Lewellen, K., 2020. Performance-induced CEO turnover. The Review of Financial Studies, forthcoming.

Kane, Y.I., 2014. The Job After Steve Jobs: Tim Cook and Apple. The Wall Street Journal, February 28.

Knyazeva, A., Knyazeva, D. and Masulis, R.W., 2013. The supply of corporate directors and director independence. The Review of Financial Studies, 26(6), pp.1561-1605.

Matthews S., 2016. Henkel's incoming CEO has 'big shoes to fill,' investors say. Bloomberg, April 11.

Milbourn, T.T., 2003. CEO reputation and stock-based compensation. Journal of Financial Economics, 68(2), pp.233-262. 
Mobbs, S., 2013. CEOs under fire: The effects of competition from inside directors on forced CEO turnover and CEO compensation. Journal of Financial and Quantitative Analysis, 48(3), pp.669-698.

Murphy, K.J., 1999. Executive compensation. Handbook of Labor Economics, 3, pp.2485-2563.

Murphy, K.J. and Zimmerman, J.L., 1993. Financial performance surrounding CEO turnover. Journal of Accounting and Economics, 16(1-3), pp.273-315.

Neyman, J. and Scott, E.L., 1948. Consistent estimates based on partially consistent observations. Econometrica: Journal of the Econometric Society, pp.1-32.

Pan, Y., Wang, T.Y. and Weisbach, M.S., 2015. Learning about CEO ability and stock return volatility. The Review of Financial Studies, 28(6), pp.1623-1666.

Parrino, R., 1997. CEO turnover and outside succession a cross-sectional analysis. Journal of Financial Economics, 46(2), pp.165-197.

Pastor, L. and Veronesi, P., 2009. Learning in financial markets. Annual Review of Financial Economics, 1(1), pp.361-381.

Peters, F.S. and Wagner, A.F., 2014. The executive turnover risk premium. The Journal of Finance, 69(4), pp.1529-1563.

Rajgopal, S., Shevlin, T. and Zamora, V., 2006. CEOs' outside employment opportunities and the lack of relative performance evaluation in compensation contracts. The Journal of Finance, 61(4), pp.1813-1844.

Taylor, L.A., 2010. Why are CEOs rarely fired? Evidence from structural estimation. The Journal of Finance, 65(6), pp.2051-2087.

Taylor, L.A., 2013. CEO wage dynamics: Estimates from a learning model. Journal of Financial Economics, 108(1), pp.79-98.

Timmermann, A.G., 1993. How learning in financial markets generates excess volatility and predictability in stock prices. The Quarterly Journal of Economics, 108(4), pp.1135-1145.

Tversky, A. and Kahneman, D., 1974. Judgment under uncertainty: Heuristics and biases. Science, 185(4157), pp.1124-1131.

Warner, J.B., Watts, R.L. and Wruck, K.H., 1988. Stock prices and top management changes. Journal of Financial Economics, 20, pp.461-492.

Weisbach, M.S., 1988. Outside directors and CEO turnover. Journal of Financial Economics, 20, pp.431-460. 
Yermack, D., 1996. Higher market valuation of companies with a small board of directors. Journal of Financial Economics, 40(2), pp.185-211.

Zhang, X.F., 2006. Information uncertainty and stock returns. The Journal of Finance, 61(1), pp.105-137. 


\section{Figure 1}

\section{Effect of Pre-Appointment Firm Performance on CEO Turnover-Performance Sensitivity}

This figure plots the CEO turnover-performance sensitivity coefficient over the range of pre-appointment firm performance. The sensitivity coefficient is estimated using the logit model in Table 2, Panel B, column (3). Empirically, a more negative sensitivity coefficient indicates a higher sensitivity of CEO dismissal to firm performance, given that firm performance is negative for dismissal cases. Gray areas indicate $90 \%$ confidence intervals. CI(Max-Min) shows the confidence intervals of the difference between the sensitivity coefficient at the minimum and maximum values of pre-appointment firm performance.

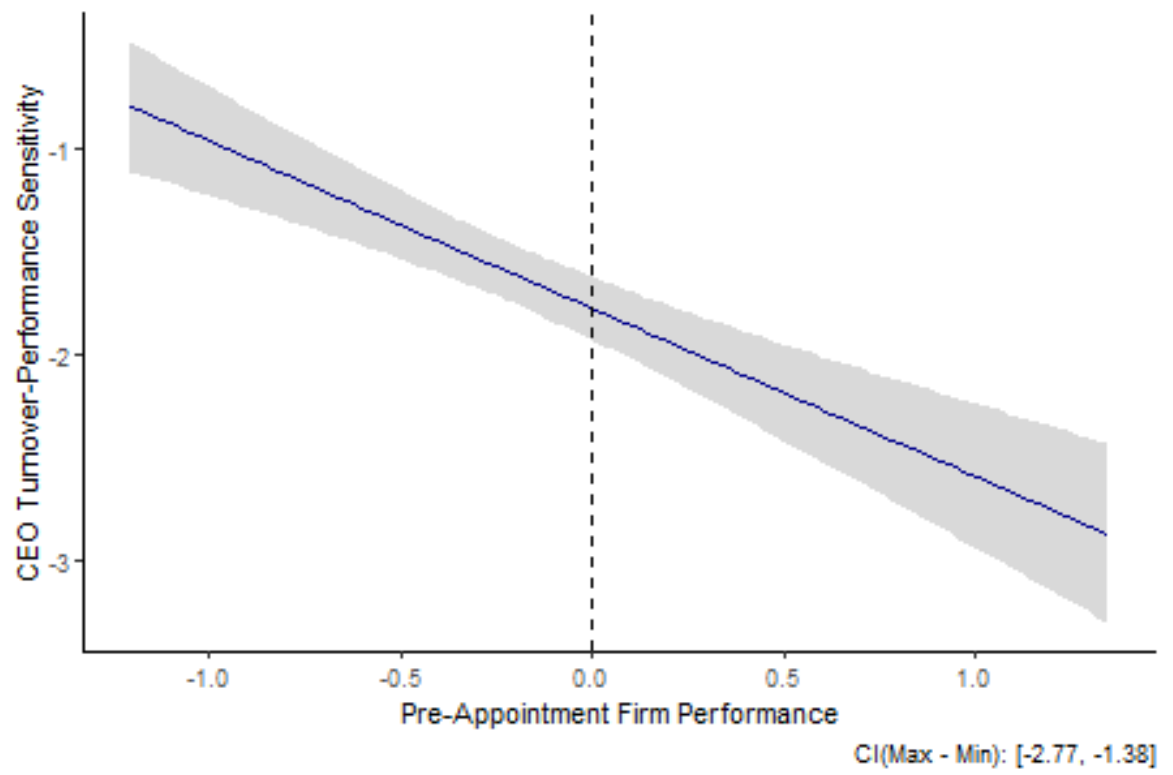




\section{Figure 2}

\section{Effect of Uncertainty about Firm Fundamentals}

This figure plots the CEO turnover-performance sensitivity coefficient over the range of pre-appointment firm performance in subsamples partitioned on four measures of a firm's fundamental uncertainty prior to the incumbent CEO's appointment. Panel A uses idiosyncratic volatility to proxy for a firm's fundamental uncertainty, Panel B uses firm size, Panel C uses firm age, and Panel D uses analyst forecast dispersion. In each panel, we split the sample into low and high groups based on the bottom and top terciles of each measure's distribution. All results are estimated based on regressions in Table 4, except that we use a logit model. Colored areas indicate $90 \%$ confidence intervals. CI(Max-Min) shows the confidence intervals of the difference between the sensitivity coefficient at the minimum and maximum values of pre-appointment firm performance.

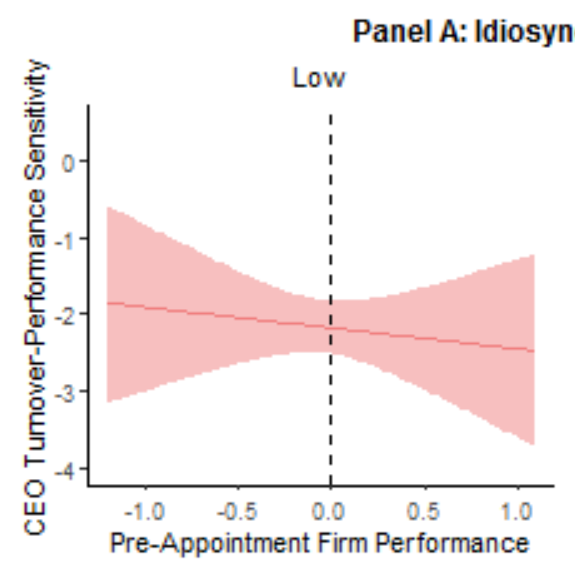

CI(Max - Min): [-3.007, 1.874]

\section{Panel C: Firm Age}

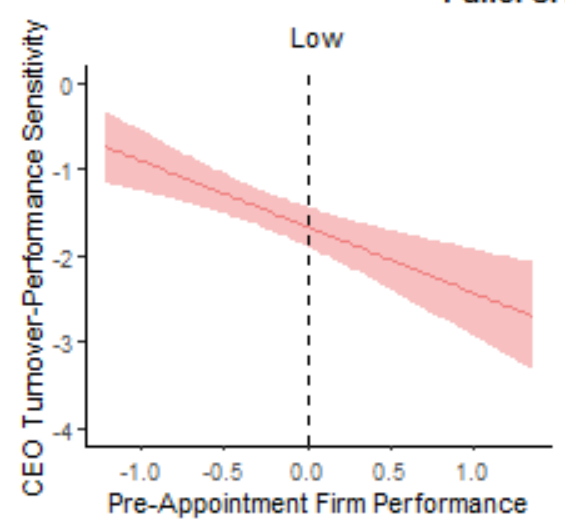

$\mathrm{Cl}(\operatorname{Max}-\mathrm{Min}):[-2.904,-1.001]$

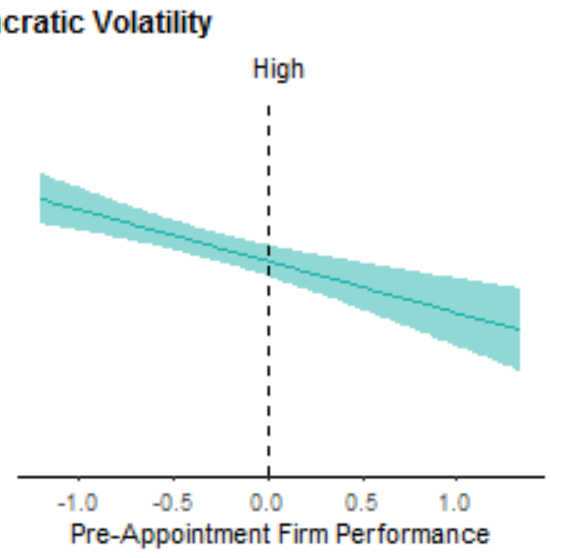

$\mathrm{Cl}(\mathrm{Max}-\mathrm{Min}):[-2.502,-0.935]$

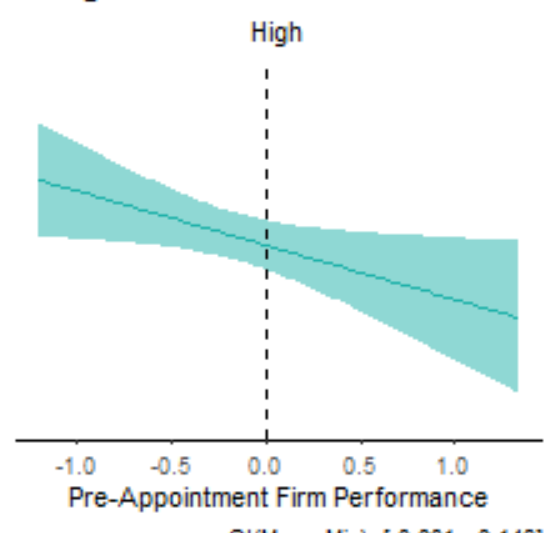

$\mathrm{Cl}(\mathrm{Max}-\mathrm{Min}):[-3.031,-0.148]$

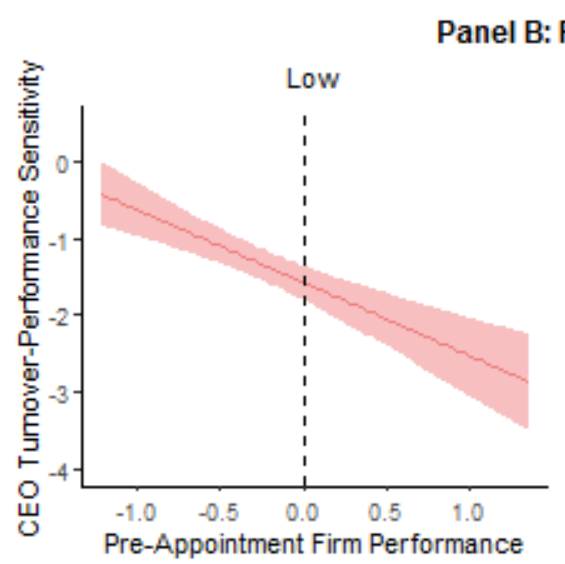

Cl(Max - Min): [-3.381, -1.479]

Panel D: Analyst Forecast Dispersion
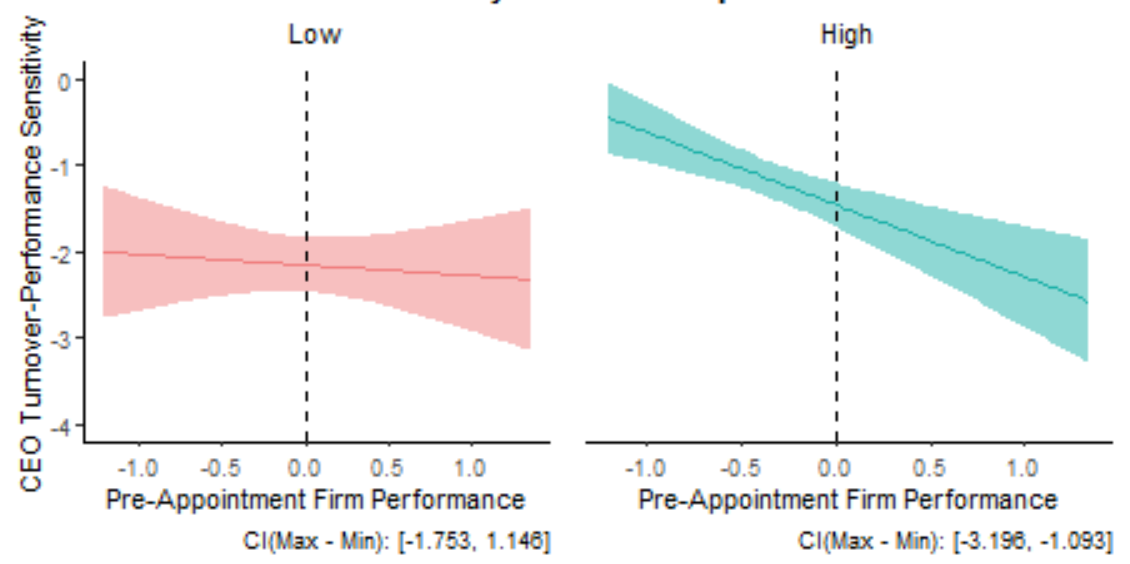
Table 1

\section{Summary Statistics}

This table presents an overview of the CEO turnover data set from 1993 to 2017. Panel A shows the number of observations and the frequency of CEO turnovers in the sample. Panel B shows firm and CEO characteristics by CEO retention outcome. All continuous variables are winsorized at the $1 \%$ level.

\begin{tabular}{|c|c|c|c|c|c|}
\hline \multicolumn{5}{|c|}{ Panel A: Frequency of CEO Turnovers } & \\
\hline $\begin{array}{c}\text { Number of Firm- } \\
\text { Quarters }\end{array}$ & $\begin{array}{c}\text { Number of } \\
\text { CEO } \\
\text { Turnovers }\end{array}$ & $\begin{array}{c}\text { Percentage of } \\
\text { Firm-Quarters } \\
\text { with CEO } \\
\text { Turnovers }\end{array}$ & $\begin{array}{l}\text { Number of } \\
\text { Performance- } \\
\text { Induced CEO } \\
\text { Turnovers }\end{array}$ & $\begin{array}{c}\text { Percentage of } \\
\text { Firm-Quarters } \\
\text { with } \\
\text { Performance- } \\
\text { Induced CEO } \\
\text { Turnovers }\end{array}$ & \\
\hline 81,935 & 2,073 & $2.53 \%$ & 1,390 & $1.70 \%$ & \\
\hline \multicolumn{6}{|c|}{ Panel B: Firm Characteristics and CEO Characteristics by CEO Retention Outcome } \\
\hline & Mean & St.Dev & $\mathrm{p} 25$ & Median & p75 \\
\hline \multicolumn{6}{|c|}{ I. CEO Is Retained $(N=\overline{\mathbf{7 9 , 8 6 2})}$} \\
\hline Log of book assets & 7.981 & 3.063 & 6.725 & 7.886 & 9.147 \\
\hline Book-to-market ratio & 0.552 & 0.201 & 0.277 & 0.461 & 0.714 \\
\hline Stock return volatility & 0.380 & 0.043 & 0.235 & 0.326 & 0.461 \\
\hline Firm stock returns & 0.132 & 0.184 & -0.117 & 0.098 & 0.317 \\
\hline ROA $(\%)$ & 0.897 & 6.005 & 0.274 & 1.043 & 2.041 \\
\hline \multicolumn{6}{|l|}{ CEO characteristics: } \\
\hline$\overline{\text { Age }}$ & 54.7 & 38.7 & 50 & 55 & 59 \\
\hline Tenure (in years) & 8.8 & 21.6 & 5 & 8 & 12 \\
\hline Retirement age $(63-66)$ & $6.9 \%$ & $6.4 \%$ & 0 & 0 & 0 \\
\hline \multicolumn{6}{|c|}{ II. Performance-Induced CEO Turnover $(N=1,390)$} \\
\hline \multicolumn{6}{|c|}{ Firm characteristics: } \\
\hline$\overline{\log \text { of book assets }}$ & 7.800 & 3.475 & 6.479 & 7.747 & 9.081 \\
\hline Book-to-market ratio & 0.678 & 0.307 & 0.334 & 0.575 & 0.867 \\
\hline Stock return volatility & 0.440 & 0.056 & 0.270 & 0.382 & 0.542 \\
\hline Firm stock returns & -0.072 & 0.163 & -0.337 & -0.086 & 0.119 \\
\hline ROA $(\%)$ & -0.074 & 9.639 & -0.589 & 0.547 & 1.503 \\
\hline \multicolumn{6}{|l|}{ CEO characteristics: } \\
\hline Age & 56.9 & 44.0 & 52 & 58 & 62 \\
\hline Tenure (in years) & 5.6 & 12.5 & 3 & 5 & 8 \\
\hline Retirement age $(63-66)$ & $14.8 \%$ & $12.6 \%$ & 0 & 0 & 0 \\
\hline \multicolumn{6}{|c|}{ III. Non-Performance-Induced CEO Turnover $(N=683)$} \\
\hline \multicolumn{6}{|c|}{ Firm characteristics: } \\
\hline Log of book assets & 8.361 & 3.033 & 7.079 & 8.199 & 9.622 \\
\hline Book-to-market ratio & 0.469 & 0.126 & 0.254 & 0.382 & 0.626 \\
\hline Stock return volatility & 0.336 & 0.032 & 0.208 & 0.291 & 0.403 \\
\hline Firm stock returns & 0.207 & 0.118 & 0.003 & 0.176 & 0.370 \\
\hline ROA $(\%)$ & 1.209 & 4.421 & 0.508 & 1.219 & 2.216 \\
\hline \multicolumn{6}{|l|}{ CEO characteristics: } \\
\hline Age & 59.9 & 40.6 & 56 & 61 & 64 \\
\hline Tenure (in years) & 6.7 & 17.3 & 4 & 6 & 9 \\
\hline Retirement age $(63-66)$ & $24.0 \%$ & $18.3 \%$ & 0 & 0 & 0 \\
\hline
\end{tabular}


Table 2

Effect of Pre-Appointment Firm Performance on CEO Turnover-Performance Sensitivity

This table examines the effect of pre-appointment firm performance on CEO turnover-performance sensitivity. The dependent variable in columns (1) to (2) is TURNOVER $R_{i, t}$, a dummy variable equals one if the name of the CEO in quarter $t+1$ is different from the name of the CEO in quarter $t$ in ExecuComp database, and zero otherwise. The dependent variable in columns (3) to (4) is PERF_TURNOVER $R_{i, t}$, a dummy variable equals one if the CEO is dismissed due to performance-related reasons in quarter $t+1$, and zero otherwise. The definition of PERF_TURNOVER ${ }_{i, t}$ follows Pan et al. (2015). Our variable of interest is $P E R F_{i, t} \times P A S T_{-} P E R F_{i-1}$, where $P E R F_{i, t}$ measures current firm performance using idiosyncratic four-quarter cumulative stock returns and $P A S T P E R F_{i-1}$ measures pre-appointment firm performance using idiosyncratic four-quarter cumulative stock returns ending in the last quarter of the prior CEO's tenure. Idiosyncratic stock returns are estimated as the residual from regressing firm stock returns on equal-weighted industry stock returns. In columns (2) and (4), we split the current firm performance into POS_PERF $F_{i, t}$ and $N E G_{-} P E R F_{i, t}$, and interact them with PAST_PERF $F_{i-1}$, respectively. POS_PERF $\left(N E G_{-} P E \bar{R} F_{i, t}\right)$ is equal to the value of $P E R F_{i, t}$ if $P E R F_{i, t}$ is positive (negative), and zero otherwise. Panel $\mathrm{A}$ presents the results using a Cox hazard model. We refer to column (3) as our baseline specification in later tables unless otherwise noted. Panel B presents the results using a logit model. All variable definitions are in the Appendix. All continuous variables are winsorized at the $1 \%$ level. z-statistics based on standard errors clustered at the firm level are reported in the parentheses. $* * *, * *$, and $*$ denote significant levels at $1 \%, 5 \%$, and $10 \%$, respectively.

\begin{tabular}{|c|c|c|c|c|}
\hline \multicolumn{5}{|l|}{ Panel A: Cox Hazard Model } \\
\hline & \multicolumn{2}{|c|}{$T U R N O V E R_{i, t}$} & \multicolumn{2}{|c|}{$P E R F_{-} T U R N O V E R_{i, t}$} \\
\hline & (1) & (2) & (3) & (4) \\
\hline$P E R F_{i, t}$ & $\begin{array}{c}-0.877 * * * \\
(-11.595)\end{array}$ & & $\begin{array}{c}-1.734 * * * \\
(-16.173)\end{array}$ & \\
\hline POS_PERF $F_{i, t}$ & & $\begin{array}{c}-0.577 * * * \\
(-4.182)\end{array}$ & & $\begin{array}{c}-1.612 * * * \\
(-4.930)\end{array}$ \\
\hline$N E G_{-} P E R F_{i, t}$ & & $\begin{array}{c}-1.094 * * * \\
(-8.958)\end{array}$ & & $\begin{array}{c}-1.810 * * * \\
(-13.342)\end{array}$ \\
\hline$P A S T_{-} P E R F_{i-1}$ & $\begin{array}{c}-0.146 * * * \\
(-2.689)\end{array}$ & $\begin{array}{c}-0.230 * * * \\
(-2.910)\end{array}$ & $\begin{array}{c}-0.222 * * * \\
(-2.712)\end{array}$ & $\begin{array}{l}-0.165 \\
(-1.613)\end{array}$ \\
\hline$P E R F_{i, t} \times P A S T \_P E R F_{i-1}$ & $\begin{array}{c}-0.516 * * * \\
(-4.018)\end{array}$ & & $\begin{array}{c}-0.770 * * * \\
(-4.478)\end{array}$ & \\
\hline$P O S \_P E R F_{i, t} \times P A S T \_P E R F_{i-1}$ & & $\begin{array}{c}-0.153 \\
(-0.703)\end{array}$ & & $\begin{array}{l}-1.026 * \\
(-1.913)\end{array}$ \\
\hline$N E G_{-} P E R F_{i, t} \times P A S T_{-} P E R F_{i-1}$ & & $\begin{array}{c}-0.720 * * * \\
(-3.764)\end{array}$ & & $\begin{array}{c}-0.649 * * * \\
(-3.374)\end{array}$ \\
\hline$S I Z E_{i, t}$ & $\begin{array}{c}0.010 \\
(0.754)\end{array}$ & $\begin{array}{c}0.013 \\
(0.936)\end{array}$ & $\begin{array}{c}-0.005 \\
(-0.286)\end{array}$ & $\begin{array}{c}-0.004 \\
(-0.219)\end{array}$ \\
\hline$V O L_{i, t}$ & $\begin{array}{c}0.798 * * * \\
(6.863)\end{array}$ & $\begin{array}{c}0.722 * * * \\
(5.918)\end{array}$ & $\begin{array}{c}1.038 * * * \\
(7.505)\end{array}$ & $\begin{array}{c}1.000 * * * \\
(7.305)\end{array}$ \\
\hline$B M_{i, t}$ & $\begin{array}{c}0.048 \\
(1.042)\end{array}$ & $\begin{array}{c}0.045 \\
(0.981)\end{array}$ & $\begin{array}{c}0.153^{* * * *} \\
(3.115)\end{array}$ & $\begin{array}{c}0.151 * * * \\
(3.078)\end{array}$ \\
\hline$L O G A G E_{i, t}$ & $\begin{array}{l}3.959 * * * \\
(15.725)\end{array}$ & $\begin{array}{l}3.963 * * * \\
(15.779)\end{array}$ & $\begin{array}{c}2.659 * * * \\
(9.031)\end{array}$ & $\begin{array}{c}2.658 * * * \\
(9.044)\end{array}$ \\
\hline$R E T I R E M E N T_{i, t}$ & $\begin{array}{c}0.453 * * * \\
(7.201)\end{array}$ & $\begin{array}{c}0.455 * * * \\
(7.217)\end{array}$ & $\begin{array}{c}0.429 * * * \\
(5.268)\end{array}$ & $\begin{array}{c}0.429 * * * \\
(5.271)\end{array}$ \\
\hline Year-Quarter Fixed Effects & Yes & Yes & Yes & Yes \\
\hline$N$ & 81,935 & 81,935 & 81,935 & 81,935 \\
\hline Pseudo R-squared & 0.026 & 0.026 & 0.035 & 0.035 \\
\hline
\end{tabular}




\begin{tabular}{|c|c|c|c|c|}
\hline \multicolumn{5}{|l|}{ Panel B: Logit Model } \\
\hline & \multicolumn{2}{|c|}{ TURNOVER $R_{i, t}$} & \multicolumn{2}{|c|}{ PERF_TURNOVER $R_{i, t}$} \\
\hline & (1) & (2) & (3) & (4) \\
\hline \multirow[t]{2}{*}{$P E R F_{i, t}$} & $-0.908^{* * *}$ & & $-1.784 * * *$ & \\
\hline & $(-11.567)$ & & $(-16.014)$ & \\
\hline \multirow[t]{2}{*}{ POS_PERF $F_{i, t}$} & & $-0.586^{* * *}$ & & $-1.610^{* * *}$ \\
\hline & & $(-4.147)$ & & $(-4.906)$ \\
\hline \multirow[t]{2}{*}{$N E G_{-} P E R F_{i, t}$} & & $-1.151^{* * *}$ & & $-1.885^{* * *}$ \\
\hline & & $(-8.950)$ & & $(-13.304)$ \\
\hline \multirow[t]{2}{*}{$P A S T_{-} P E R F_{i-1}$} & $-0.165^{* * *}$ & $-0.243 * * *$ & $-0.238^{* * *}$ & $-0.181 *$ \\
\hline & $(-2.816)$ & $(-2.893)$ & $(-2.843)$ & $(-1.732)$ \\
\hline \multirow[t]{2}{*}{$P E R F_{i, t} \times P A S T_{-} P E R F_{i-1}$} & $-0.503 * * *$ & & $-0.772 * * *$ & \\
\hline & $(-3.760)$ & & $(-4.276)$ & \\
\hline \multirow[t]{2}{*}{$P O S_{-} P E R F_{i, t} \times P A S T_{-} P E R F_{i-1}$} & & -0.159 & & $-1.009 *$ \\
\hline & & $(-0.722)$ & & $(-1.880)$ \\
\hline \multirow[t]{2}{*}{$N E G_{-} P E R F_{i, t} \times P A S T_{-} P E R F_{i-1}$} & & $-0.696 * * *$ & & $-0.645 * * *$ \\
\hline & & $(-3.433)$ & & $(-3.195)$ \\
\hline \multirow[t]{2}{*}{$S I Z E_{i, t}$} & 0.011 & 0.013 & -0.006 & -0.004 \\
\hline & $(0.716)$ & $(0.895)$ & $(-0.314)$ & $(-0.234)$ \\
\hline \multirow[t]{2}{*}{$V O L_{i, t}$} & $0.924 * * *$ & $0.838 * * *$ & $1.150^{* * *}$ & $1.102 * * *$ \\
\hline & $(7.296)$ & $(6.323)$ & $(7.886)$ & $(7.646)$ \\
\hline \multirow[t]{2}{*}{$B M_{i, t}$} & 0.060 & 0.056 & $0.164 * * *$ & $0.161 * * *$ \\
\hline & $(1.157)$ & $(1.086)$ & $(3.107)$ & $(3.062)$ \\
\hline \multirow[t]{2}{*}{$L O G A G E_{i, t}$} & $3.728 * * *$ & $3.733 * * *$ & $2.511 * * *$ & $2.509 * * *$ \\
\hline & $(13.866)$ & $(13.909)$ & $(8.107)$ & $(8.114)$ \\
\hline \multirow[t]{2}{*}{ RETIREMENT $T_{i, t}$} & $0.468 * * *$ & $0.469 * * *$ & $0.430 * * *$ & $0.431 * * *$ \\
\hline & $(7.107)$ & $(7.117)$ & $(5.107)$ & $(5.110)$ \\
\hline \multirow[t]{2}{*}{$T_{E N U R E_{i, t}}$} & $0.004 * * *$ & $0.004 * * *$ & $0.004 * * *$ & $0.004 * * *$ \\
\hline & $(6.759)$ & $(6.782)$ & $(5.273)$ & $(5.311)$ \\
\hline Year-Quarter Fixed Effects & Yes & Yes & Yes & Yes \\
\hline Constant & Yes & Yes & Yes & Yes \\
\hline$N$ & 81,693 & 81,693 & 81,693 & 81,693 \\
\hline Pseudo R-squared & 0.070 & 0.070 & 0.081 & 0.081 \\
\hline
\end{tabular}


Table 3

Marginal CEO Turnover-Performance Sensitivities at Different Percentiles of Pre-Appointment Firm Performance

This table presents marginal sensitivities of firm performance on performance-induced CEO turnovers at different percentiles of pre-appointment firm performance, estimated using the logit model in column (3) of Table 2, Panel B. All continuous variables are winsorized at the 1\% level. $z$-statistics are based on standard errors clustered at the firm level.

\begin{tabular}{lcc}
\hline & $\begin{array}{c}\text { Marginal sensitivity of } \\
\text { PERF } F_{i, t} \text { on } \\
\text { PERF_TURNOVER }\end{array}$ & $z$-statistics \\
\cline { 2 - 3 } PAST_PERF $F_{i-1}$ at 10 th percentile & -0.180 & -3.060 \\
$P A S T_{-} P E R F_{i-1}$ at 30 th percentile & -0.386 & -2.800 \\
$P A S T_{-} P E R F_{i-1}$ at 50 th percentile & -0.483 & -3.090 \\
$P A S T_{-} P E R F_{i-1}$ at 70 th percentile & -0.530 & -2.970 \\
PAST_PERF $F_{i-1}$ at 90 th percentile & -0.564 & -2.630 \\
\hline
\end{tabular}




\section{Table 4}

\section{Alternative Constructions of Main Variables}

This table shows robustness to alternative choices in the constructions of our main variables. Panel A shows robustness to alternative time windows of measuring pre-appointment firm performance. Column (1) measures pre-appointment firm performance using the average of idiosyncratic four-quarter cumulative stock returns over the prior CEO's entire tenure. Panel B reports robustness to alternative measures of firm performance. Column (2) measures firm performance using the average ROA (in percentage) over the current and past three quarters. Column (3) uses four-quarter cumulative stock returns. Column (4) uses industry-mean adjusted four-quarter cumulative stock returns. Column (5) shows the results of strong-form relative performance evaluation with peer performance calculated as the value-weighted four-quarter cumulative stock returns on CRSP from the same industry as the sample firm, excluding the sample firm itself. Panel C presents robustness to alternative turnover classifications. The dependent variable in column (6) is TURNOVER_JLi,t, of which the definition follows Jenter and Lewellen (2019). The dependent variable in column (7) is FORCED $D_{i, t}$ of which the procedure is proposed by Parrino (1997). For brevity, we report only the interaction effects, but all direct effects are included in the regressions. All continuous variables are winsorized at the $1 \%$ level. $z$-statistics based on standard errors clustered at the firm level are reported in the parentheses. $* * *, * *$, and $*$ denote significant levels at $1 \%, 5 \%$, and $10 \%$, respectively.

\begin{tabular}{|c|c|c|c|c|c|c|c|}
\hline & $(1)$ & $(2)$ & $R F_{-} T U R N O I$ & (4) & $(5)$ & $\begin{array}{c}\text { TURNOVER_JL } L_{i, t} \\
(6)\end{array}$ & $\begin{array}{l}\text { FORCED } \\
\text { (7) }\end{array}$ \\
\hline \multicolumn{8}{|l|}{ Panel A: Full Pre-Appointment Firm Performance } \\
\hline$P E R F_{i, t} \times$ PAST_PERF_TENURE $E_{i-1}$ & $\begin{array}{l}-0.695 * * \\
(-2.555)\end{array}$ & & & & & & \\
\hline \multicolumn{8}{|c|}{ Panel B: Alternative Measures of Firm Performance } \\
\hline$R O A_{i, t} \times P A S T_{-} R O A_{i-1}$ & & $\begin{array}{c}-0.008 * * * \\
(-4.288)\end{array}$ & & & & & \\
\hline$P E R F_{-} R A W_{i, t} \times P A S T_{-} P E R F_{-} R A W_{i-1}$ & & & $\begin{array}{c}-0.547 * * * \\
(-2.842)\end{array}$ & & & & \\
\hline$P E R F_{-} I N D A D J_{i, t} \times P A S T_{-} P E R F_{-} I N D A D J_{i-1}$ & & & & $\begin{array}{c}-0.731 * * * \\
(-4.557)\end{array}$ & & & \\
\hline$P E R F_{-} V W_{i, t} \times P A S T_{-} P E R F_{-} V W_{i-1}$ & & & & & $\begin{array}{c}-0.777 * * * \\
(-3.822)\end{array}$ & & \\
\hline \multicolumn{8}{|l|}{ Panel C: Alternative Turnover Classifications } \\
\hline$P E R F_{i, t} \times P A S T_{-} P E R F_{i-1}$ & & & & & & $\begin{array}{c}-1.292 * * * \\
(-6.825)\end{array}$ & $\begin{array}{c}-0.852 * * * \\
(-3.636)\end{array}$ \\
\hline Year-Quarter Fixed Effects & Yes & Yes & Yes & Yes & Yes & Yes & Yes \\
\hline Firm and CEO Characteristics & Yes & Yes & Yes & Yes & Yes & Yes & Yes \\
\hline$N$ & 81,935 & 81,935 & 81,935 & 81,935 & 81,935 & 81,935 & 81,935 \\
\hline Pseudo $R$-squared & 0.035 & 0.034 & 0.024 & 0.033 & 0.034 & 0.034 & 0.036 \\
\hline
\end{tabular}


Table 5

Effect of Uncertainty about Firm Fundamentals

This table shows the effect of pre-appointment firm performance on CEO turnover-performance sensitivity in subsamples partitioned based on measures of uncertainty about the firm's fundamentals before the incumbent CEO takes office. We use four measures to proxy for the firm's fundamental uncertainty: (1) idiosyncratic volatility, (2) firm size, (3) firm age, and (4) analyst forecast dispersion. The sample is partitioned based on the bottom and top terciles of each measure's distribution. All variable definitions are in the Appendix. All continuous variables are winsorized at the 1\% level. $z$-statistics based on standard errors clustered at the firm level are reported in the parentheses. $* * *, * *$, and $*$ denote significant levels at $1 \%, 5 \%$, and $10 \%$, respectively.

\begin{tabular}{|c|c|c|c|c|c|c|c|c|}
\hline & \multicolumn{8}{|c|}{ PERF_TURNOVER $R_{i, t}$} \\
\hline & \multicolumn{2}{|c|}{ Idiosyncratic Volatility } & \multicolumn{2}{|c|}{ Firm Size } & \multicolumn{2}{|c|}{ Firm Age } & \multicolumn{2}{|c|}{$\begin{array}{c}\text { Analyst Forecast } \\
\text { Dispersion } \\
\end{array}$} \\
\hline & $\begin{array}{c}\text { Low } \\
(1)\end{array}$ & $\begin{array}{l}\text { High } \\
(2)\end{array}$ & $\begin{array}{l}\text { Low } \\
(3)\end{array}$ & $\begin{array}{l}\text { High } \\
(4)\end{array}$ & $\begin{array}{l}\text { Low } \\
(5)\end{array}$ & $\begin{array}{l}\text { High } \\
(6)\end{array}$ & $\begin{array}{l}\text { Low } \\
(7)\end{array}$ & $\begin{array}{l}\text { High } \\
(8)\end{array}$ \\
\hline$P E R F_{i, t}$ & $\begin{array}{c}-2.131 * * * \\
(-8.720)\end{array}$ & $\begin{array}{c}-1.398 * * * \\
(-9.816)\end{array}$ & $\begin{array}{l}-1.568 * * * \\
(-10.207)\end{array}$ & $\begin{array}{c}-1.854 * * * \\
(-8.337)\end{array}$ & $\begin{array}{c}-1.628 * * * \\
(-10.054)\end{array}$ & $\begin{array}{c}-1.875^{* * *} \\
(-8.352)\end{array}$ & $\begin{array}{c}-2.147 * * * \\
(-9.046)\end{array}$ & $\begin{array}{c}-1.421 * * * \\
(-9.469)\end{array}$ \\
\hline$P A S T_{-} P E R F_{i-1}$ & $\begin{array}{l}-0.169 \\
(-0.706)\end{array}$ & $\begin{array}{l}-0.208^{* *} \\
(-2.174)\end{array}$ & $\begin{array}{c}-0.363 * * * \\
(-3.051)\end{array}$ & $\begin{array}{l}-0.074 \\
(-0.397)\end{array}$ & $\begin{array}{l}-0.206^{*} \\
(-1.706)\end{array}$ & $\begin{array}{l}-0.056 \\
(-0.325)\end{array}$ & $\begin{array}{c}0.111 \\
(0.679)\end{array}$ & $\begin{array}{l}-0.191^{*} \\
(-1.684)\end{array}$ \\
\hline$P E R F_{i, t} \times P A S T_{-} P E R F_{i-1}$ & $\begin{array}{c}-0.259 \\
(-0.448)\end{array}$ & $\begin{array}{c}-0.636 * * * \\
(-3.119)\end{array}$ & $\begin{array}{c}-0.953 * * * \\
(-4.663)\end{array}$ & $\begin{array}{c}-0.653 \\
(-1.362)\end{array}$ & $\begin{array}{c}-0.710 * * * \\
(-3.190)\end{array}$ & $\begin{array}{c}-0.604 \\
(-1.459)\end{array}$ & $\begin{array}{c}-0.115 \\
(-0.373)\end{array}$ & $\begin{array}{c}-0.783 * * * \\
(-3.233)\end{array}$ \\
\hline Year-Quarter Fixed Effects & Yes & Yes & Yes & Yes & Yes & Yes & Yes & Yes \\
\hline $\begin{array}{l}\text { Firm and CEO } \\
\text { Characteristics }\end{array}$ & Yes & Yes & Yes & Yes & Yes & Yes & Yes & Yes \\
\hline$N$ & 27,239 & 27,224 & 27,285 & 27,278 & 28,737 & 27,189 & 25,092 & 25,006 \\
\hline Pseudo $R$-squared & 0.055 & 0.038 & 0.043 & 0.050 & 0.044 & 0.056 & 0.056 & 0.039 \\
\hline
\end{tabular}


Table 6

Pre-Appointment Firm Performance and CEO Tenure

This table shows the effect of pre-appointment firm performance on CEO turnover-performance sensitivity as the incumbent CEO's tenure increases. We split our sample into those CEOs with at least one year, two years, three years, and more than three years since they take office and repeat our estimation within each subsample. The definitions of all variables are defined in the Appendix. All continuous variables are winsorized at the $1 \%$ level. $z$ statistics based on standard errors clustered at the firm level are reported in the parentheses. $* * *, * *$, and * denote significant levels at $1 \%, 5 \%$, and $10 \%$, respectively.

\begin{tabular}{|c|c|c|c|c|}
\hline \multirow[b]{2}{*}{ Incumbent CEO's Tenure: } & \multicolumn{4}{|c|}{ PERF_TURNOVERi,t } \\
\hline & $\begin{array}{c}\geq 1 \text { year } \\
\text { (1) }\end{array}$ & $\begin{array}{c}\geq 2 \text { years } \\
(2)\end{array}$ & $\begin{array}{c}\geq 3 \text { years } \\
\text { (3) }\end{array}$ & $\begin{array}{c}\geq 4 \text { years } \\
(4)\end{array}$ \\
\hline$P E R F_{i, t}$ & $\begin{array}{c}-1.734 * * * \\
(-16.173)\end{array}$ & $\begin{array}{c}-1.879 * * * \\
(-17.047)\end{array}$ & $\begin{array}{c}-1.947 * * * \\
(-14.788)\end{array}$ & $\begin{array}{c}-1.937 * * * \\
(-13.337)\end{array}$ \\
\hline$P A S T \_P E R F_{i-1}$ & $\begin{array}{c}-0.222 * * * \\
(-2.712)\end{array}$ & $\begin{array}{c}-0.220 * * * \\
(-2.590)\end{array}$ & $\begin{array}{c}-0.147 \\
(-1.547)\end{array}$ & $\begin{array}{c}-0.132 \\
(-1.268)\end{array}$ \\
\hline$P E R F_{i, t} \times P A S T_{-} P E R F_{i-1}$ & $\begin{array}{c}-0.770 * * * \\
(-4.478)\end{array}$ & $\begin{array}{c}-0.636 * * * \\
(-3.575)\end{array}$ & $\begin{array}{c}-0.460 * * \\
(-2.152)\end{array}$ & $\begin{array}{c}-0.309 \\
(-1.303)\end{array}$ \\
\hline Year-Quarter Fixed Effects & Yes & Yes & Yes & Yes \\
\hline Firm and CEO Characteristics & Yes & Yes & Yes & Yes \\
\hline$N$ & 81,935 & 72,040 & 55,971 & 44,064 \\
\hline Pseudo $R$-squared & 0.035 & 0.036 & 0.039 & 0.040 \\
\hline
\end{tabular}


Table 7

Alternative Explanations: Biased Assessment of CEO Quality and Quality of Corporate Governance

This table reports the test results on two alternative explanations for our main finding. Panel A reports estimates from baseline regressions in subsamples partitioned based on measures of uncertainty about the incumbent CEO's quality. We use three measures to proxy for uncertainty about the incumbent CEO's quality: (1) CEO age when the CEO takes office, (2) an indicator of whether the CEO is an outsider or not, and (3) the number of positions the CEO took prior to becoming the CEO. The sample is partitioned based on the bottom and top terciles of each measure's distribution. Panel B reports estimates from baseline regressions after controlling for measures of corporate governance as well as firm performance interacted with these measures. We use three measures to proxy for corporate governance: (1) percentage of independent directors, (2) board size, and (3) percentage of busy directors. All variable definitions are in the Appendix. All continuous variables are winsorized at the $1 \%$ level. $z$-statistics based on standard errors clustered at the firm level are reported in the parentheses $* * *, * *$, and $*$ denote significant levels at $1 \%, 5 \%$, and $10 \%$, respectively.

\begin{tabular}{|c|c|c|c|c|c|c|}
\hline \multicolumn{7}{|c|}{ Panel A: Biased Assessment of CEO Quality } \\
\hline & \multicolumn{6}{|c|}{ PERF_TURNOVER $R_{i, t}$} \\
\hline & \multicolumn{2}{|c|}{ CEO Age } & \multicolumn{2}{|c|}{ Outsider $C E O$} & \multicolumn{2}{|c|}{ Prior Experience } \\
\hline & $\begin{array}{c}\text { Low } \\
(1)\end{array}$ & $\begin{array}{l}\text { High } \\
(2)\end{array}$ & $\begin{array}{l}\text { Yes } \\
(3)\end{array}$ & $\begin{array}{l}\text { No } \\
(4) \\
\end{array}$ & $\begin{array}{l}\text { Low } \\
(5)\end{array}$ & $\begin{array}{c}\text { High } \\
(6)\end{array}$ \\
\hline$P E R F_{i, t}$ & $\begin{array}{c}-1.793 * * * \\
(-9.413)\end{array}$ & $\begin{array}{c}-1.810 * * * \\
(-11.456)\end{array}$ & $\begin{array}{c}-1.682 * * * \\
(-8.376)\end{array}$ & $\begin{array}{c}-1.751 * * * \\
(-11.391)\end{array}$ & $\begin{array}{c}-1.845^{* * *} \\
(-9.185)\end{array}$ & $\begin{array}{c}-1.635^{* * *} \\
(-6.981)\end{array}$ \\
\hline$P A S T \_P E R F_{i-1}$ & $\begin{array}{l}-0.224^{*} \\
(-1.675)\end{array}$ & $\begin{array}{c}-0.426^{* * *} \\
(-3.140)\end{array}$ & $\begin{array}{c}-0.218 \\
(-1.353)\end{array}$ & $\begin{array}{c}-0.175 \\
(-1.537)\end{array}$ & $\begin{array}{l}-0.253^{*} \\
(-1.813)\end{array}$ & $\begin{array}{c}-0.065 \\
(-0.353)\end{array}$ \\
\hline$P E R F_{i, t} \times P A S T \_P E R F_{i-1}$ & $\begin{array}{c}-0.342 \\
(-1.269)\end{array}$ & $\begin{array}{c}-1.192 * * * \\
(-5.003)\end{array}$ & $\begin{array}{c}-0.724 * * \\
(-2.066)\end{array}$ & $\begin{array}{c}-0.558 * * \\
(-2.372)\end{array}$ & $\begin{array}{c}-0.702 * * \\
(-2.418)\end{array}$ & $\begin{array}{c}-0.769 * * \\
(-2.485)\end{array}$ \\
\hline Year-Quarter Fixed Effects & Yes & Yes & Yes & Yes & Yes & Yes \\
\hline Firm and CEO Characteristics & Yes & Yes & Yes & Yes & Yes & Yes \\
\hline$N$ & 30,316 & 25,622 & 21,649 & 37,492 & 18,687 & 12,726 \\
\hline Pseudo $R$-squared & 0.045 & 0.044 & 0.042 & 0.043 & 0.053 & 0.060 \\
\hline
\end{tabular}




\begin{tabular}{|c|c|c|c|c|}
\hline \multicolumn{5}{|c|}{ Panel B: Variation in Corporate Governance } \\
\hline & \multicolumn{4}{|c|}{ PERF_TURNOVER $R_{i, t}$} \\
\hline & $(1)$ & $(2)$ & (3) & (4) \\
\hline$P E R F_{i, t}$ & $\begin{array}{c}-1.091 * * \\
(-2.147)\end{array}$ & $\begin{array}{c}0.599 \\
(0.716)\end{array}$ & $\begin{array}{c}-1.551 * * * \\
(-9.955)\end{array}$ & $\begin{array}{r}-1.658 * * * \\
(-13.851)\end{array}$ \\
\hline$P A S T_{-} P E R F_{i-1}$ & $\begin{array}{c}-0.257 * * * \\
(-2.940)\end{array}$ & $\begin{array}{c}-0.231 * * * \\
(-2.663)\end{array}$ & $\begin{array}{c}-0.240 * * * \\
(-2.759)\end{array}$ & $\begin{array}{c}-0.222 * * * \\
(-2.713)\end{array}$ \\
\hline$P E R F_{i, t} \times P A S T \_P E R F_{i-1}$ & $\begin{array}{c}-0.735 * * * \\
(-3.985)\end{array}$ & $\begin{array}{c}-0.681 * * * \\
(-3.716)\end{array}$ & $\begin{array}{c}-0.724 * * * \\
(-3.991)\end{array}$ & $\begin{array}{c}-0.771 * * * \\
(-4.478)\end{array}$ \\
\hline$I N D E P E N D E N C E_{i, t}$ & $\begin{array}{c}-0.869 * * * \\
(-2.637)\end{array}$ & & & \\
\hline$P E R F_{i, t} \times I N D E P E N D E N C E_{i, t}$ & $\begin{array}{c}-0.870 \\
(-1.341)\end{array}$ & & & \\
\hline BOARDSIZE $E_{i, t}$ & & $\begin{array}{c}-0.163 \\
(-0.861)\end{array}$ & & \\
\hline$P E R F_{i, t} \times B O A R D S I Z E_{i, t}$ & & $\begin{array}{c}-1.073 * * * \\
(-2.847)\end{array}$ & & \\
\hline$B U S Y B O A R D_{i, t}$ & & & $\begin{array}{c}0.064 \\
(0.311)\end{array}$ & \\
\hline$P E R F_{i, t} \times B U S Y B O A R D_{i, t}$ & & & $\begin{array}{c}-0.922 * * \\
(-2.094)\end{array}$ & \\
\hline$D U A L I T Y_{i, t}$ & & & & $\begin{array}{c}-0.071 \\
(-1.088)\end{array}$ \\
\hline$P E R F_{i, t} \times D_{U A L I T Y}{ }_{i, t}$ & & & & $\begin{array}{c}-0.163 \\
(-1.070)\end{array}$ \\
\hline Year-Quarter Fixed Effects & Yes & Yes & Yes & Yes \\
\hline Firm and CEO Characteristics & Yes & Yes & Yes & Yes \\
\hline$N$ & 65,348 & 65,348 & 65,295 & 81,935 \\
\hline Pseudo $R$-squared & 0.035 & 0.035 & 0.034 & 0.035 \\
\hline
\end{tabular}




\section{Table 8}

Type of a Predecessor's Turnover: Performance-Induced or Non-Performance-Induced

This table shows the effect of pre-appointment firm performance on CEO turnover-performance sensitivity in subsamples, where the predecessor CEO's turnover type is performance-induced and non-performance-induced. All variable definitions are in the Appendix. All continuous variables are winsorized at the 1\% level. $z$-statistics based on standard errors clustered at the firm level are reported in the parentheses. $* * *, * *$, and $*$ denote significant levels at $1 \%, 5 \%$, and $10 \%$, respectively.

\begin{tabular}{|c|c|c|}
\hline \multirow[b]{2}{*}{ The Type of a Predecessor's Turnover: } & \multicolumn{2}{|c|}{$P E R F_{-} T U R N O V E R_{i, t}$} \\
\hline & $\begin{array}{l}\text { Performance-Induced } \\
\text { (1) }\end{array}$ & $\begin{array}{c}\text { Non-Performance-Induced } \\
(2)\end{array}$ \\
\hline \multirow[t]{2}{*}{$P E R F_{i, t}$} & $-1.584 * * *$ & $-2.021 * * *$ \\
\hline & $(-11.110)$ & $(-10.067)$ \\
\hline \multirow[t]{2}{*}{$P A S T \_P E R F_{i-1}$} & $-0.206^{*}$ & -0.068 \\
\hline & $(-1.875)$ & $(-0.435)$ \\
\hline \multirow{2}{*}{$P E R F_{i, t} \times P A S T_{-} P E R F_{i-1}$} & $-0.638 * * *$ & $-0.556 * *$ \\
\hline & $(-2.743)$ & $(-1.985)$ \\
\hline Year-Quarter Fixed Effects & Yes & Yes \\
\hline Firm and CEO Characteristics & Yes & Yes \\
\hline$N$ & 49,365 & 32,410 \\
\hline Pseudo $R$-squared & 0.033 & 0.056 \\
\hline
\end{tabular}




\begin{tabular}{|c|c|}
\hline Variable & Definition \\
\hline \multicolumn{2}{|c|}{ A. Variables in the baseline specification } \\
\hline TURNOVER $R_{i, t}$ & $\begin{array}{l}\text { An indicator variable that equals one in quarter } t \text { if the name of the CEO in quarter } \\
t \text { is different from the name of the CEO in quarter } t+1 \text {, and zero otherwise. }\end{array}$ \\
\hline PERF_TURNOVER $R_{i, t}$ & $\begin{array}{l}\text { An indicator variable that equals one in quarter } t \text { if the CEO left the office in } \\
\text { quarter } t+1 \text { due to performance-related reasons, and zero otherwise. The definitions } \\
\text { of performance-induced turnover and non-performance-induced turnover follow } \\
\text { Pan et al. (2015). A turnover event is classified as non-performance-induced if the } \\
\text { turnover is caused by death (ExecuComp variable reason is "deceased") or } \\
\text { retirement (ExecuComp variable reason is "retired" or variable age is on and } \\
\text { above } 65 \text { ) of the departing CEO. For the turnover that is caused by retirement, we } \\
\text { additionally require the firm's stock performance in the year prior to the turnover } \\
\text { event to be above the industry-year median. Also, the turnover following both } \\
\text { good performance (both stock returns and ROA above industry-year median) as } \\
\text { well as low idiosyncratic volatility (below industry-year median) is classified as } \\
\text { non-performance-induced. The remaining turnovers are classified as performance- } \\
\text { induced. }\end{array}$ \\
\hline$P E R F_{i, t}$ & $\begin{array}{l}\text { Firm performance is measured as idiosyncratic stock returns after decomposing } \\
\text { firm stock returns into a predictable component caused by equal-weighted industry } \\
\text { peer performance and an idiosyncratic component. Firm stock returns are } \\
\text { measured as cumulative daily stock returns over the current and prior three } \\
\text { quarters. The industry definitions follow Fama and French (1997) classification } \\
\text { into } 49 \text { industries, with all firms in the "Other" industry dropped from the analysis. } \\
\text { The details are explained in Section 3.2. }\end{array}$ \\
\hline POS_PERF & $P O S \_P E R F_{i, t}$ equals $P E R F_{i, t}$ if $P E R F_{i, t}$ is positive, and zero otherwise. \\
\hline$N E G_{-} P E R F_{i, t}$ & $N E G_{-} P E R F_{i, t}$ equals $P E R F_{i, t}$ if $P E R F_{i, t}$ is negative, and zero otherwise. \\
\hline$P A S T \_P E R F_{i-1}$ & $\begin{array}{l}\text { Pre-appointment firm performance, measured as idiosyncratic four-quarter } \\
\text { cumulative stock returns ending in the last quarter of the prior CEO's tenure. } \\
\text { Idiosyncratic stock returns are estimated using residuals obtained from regressing } \\
\text { firm stock returns onto equal-weighted stock returns on CRSP from the same } \\
\text { industry as the sample firm, excluding the sample firm itself. The industry } \\
\text { definitions follow Fama and French (1997) classification into } 49 \text { industries, with } \\
\text { all firms in the "Other" industry dropped from the analysis. The details are } \\
\text { explained in Section 3.2. }\end{array}$ \\
\hline$S I Z E_{i, t}$ & Natural logarithm of book assets at the end of each fiscal quarter. \\
\hline$V O L_{i, t}$ & $\begin{array}{l}\text { The standard deviation of monthly stock returns over the current and past } 35 \\
\text { months, aggregated to the annual level. }\end{array}$ \\
\hline$B M_{i, t}$ & $\begin{array}{l}\text { Book value of the firm's equity divided by the market value of the firm's equity at } \\
\text { the end of the fiscal quarter. }\end{array}$ \\
\hline$L O G A G E_{i, t}$ & Natural logarithm of CEO age in years. \\
\hline RETIREMENT $T_{i, t}$ & $\begin{array}{l}\text { An indicator variable that equals one if the CEO is between and including age } 63 \\
\text { and } 66 \text {, and zero otherwise. }\end{array}$ \\
\hline TENURE $E_{i, t}$ & Number of months since the CEO takes office. \\
\hline \multicolumn{2}{|c|}{ B. Uncertainty about the firm's fundamentals } \\
\hline Idiosyncratic Volatility & $\begin{array}{l}\text { The volatility of residual daily stock return from the Fama-French three-factor } \\
\text { model, aggregated to the quarterly level. }\end{array}$ \\
\hline Firm Size & Natural logarithm of book assets at the end of each fiscal quarter. \\
\hline Firm Age & Age of the firm since IPO, using the first day appear in CRSP. \\
\hline Analyst Forecast Dispersion & $\begin{array}{l}\text { The standard deviation of the latest analyst quarterly earnings forecasts, scaled by } \\
\text { the stock price } 30 \text { trading days prior to the quarterly earnings announcement. }\end{array}$ \\
\hline
\end{tabular}




\begin{tabular}{|c|c|}
\hline \multicolumn{2}{|c|}{ C. Uncertainty about the incumbent CEO's quality } \\
\hline CEO Age & Natural logarithm of CEO age in years. \\
\hline Outsider CEO & An indicator that equals one if the $\mathrm{CEO}$ is hired from outside, and zero otherwise. \\
\hline Prior Experience & $\begin{array}{l}\text { The number of positions the CEO took prior to become the CEO (both within the } \\
\text { current firm and in other companies that are available in BoardEx). }\end{array}$ \\
\hline \multicolumn{2}{|c|}{ D. Corporate governance } \\
\hline INDEPENDENCE $E_{i, t}$ & $\begin{array}{l}\text { The number of independent directors scaled by the total number of directors, } \\
\text { constructed for each firm-year. }\end{array}$ \\
\hline$B O A R D S I Z E_{i, t}$ & Natural logarithm of the number of directors, constructed for each firm-year. \\
\hline$B U S Y B O A R D_{i, t}$ & $\begin{array}{l}\text { The number of independent directors who hold three or more board seats scaled by } \\
\text { the total number of independent directors, constructed for each firm-year. }\end{array}$ \\
\hline DUALITY ${ }_{i, t}$ & $\begin{array}{l}\text { An indicator that equals one if the CEO also serves as board chair, and zero } \\
\text { otherwise. }\end{array}$ \\
\hline
\end{tabular}


Internet Appendix to:

\title{
Big Shoes to Fill: CEO Turnover and Pre-Appointment Firm Performance
}

\author{
Miguel Minutti-Meza, Dhananjay Nanda, and Rosy Xu
}

\section{Figure A1}

Marginal Interaction Effect Using the Method Described by Ai and Norton (2003)

The blue dots plot the corrected marginal effect of the interaction variable $\left(P E R F_{i, t} \times P A S T_{-} P E R F_{i-1}\right)$ using the method as in Ai and Norton (2003) across different predicted probabilities of performance-induced CEO turnovers. The red line plots the marginal interaction effect using the logit model across different predicted probabilities of performance-induced CEO turnovers.

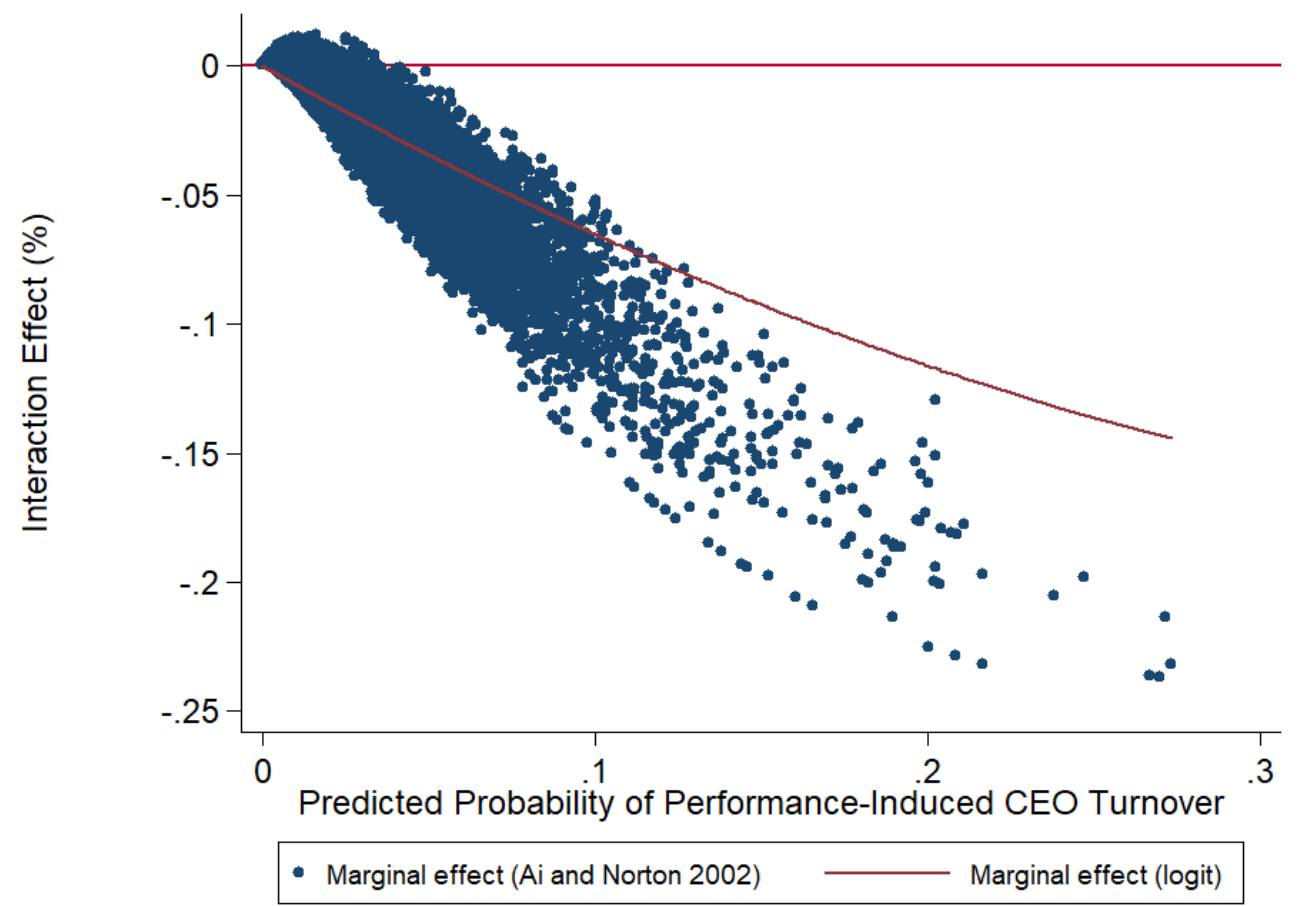




\section{Table A1}

\section{Robustness to an Alternative Sample without Interim CEOs}

This table shows robustness to an alternative sample that excludes turnover events possibly involving interim CEOs (with tenure shorter than three years). All variable definitions are in the Appendix. All continuous variables are winsorized at the $1 \%$ level. $z$-statistics based on standard errors clustered at the firm level are reported in the parentheses. $* * *, * *$, and $*$ denote significant levels at $1 \%, 5 \%$, and $10 \%$, respectively.

\begin{tabular}{|c|c|}
\hline & PERF_TURNOVER $R_{i, t}$ \\
\hline \multirow[t]{2}{*}{$P E R F_{i, t}$} & $-1.819 * * *$ \\
\hline & $(-12.308)$ \\
\hline \multirow[t]{2}{*}{$P A S T_{-} P E R F_{i-1}$} & $-0.191^{*}$ \\
\hline & $(-1.646)$ \\
\hline \multirow[t]{2}{*}{$P E R F_{i, t} \times P A S T_{-} P E R F_{i-1}$} & $-0.763 * * *$ \\
\hline & $(-3.341)$ \\
\hline Year-Quarter Fixed Effects & Yes \\
\hline Firm and CEO Characteristics & Yes \\
\hline$N$ & 73,746 \\
\hline Pseudo $R$-squared & 0.047 \\
\hline
\end{tabular}

\section{Table A2}

\section{Robustness to Estimating $\mathrm{Y} 1$ at Firm and CEO-Firm Levels}

In Section 3.3, we estimate firm performance by decomposing the firm stock return into an industry peer-specific component and an idiosyncratic component. In this table, we allow the sensitivity ( 1 ) of firm stock return to peer stock returns to differ across firms and CEO-firm pairs. All variable definitions are in the Appendix. All continuous variables are winsorized at the $1 \%$ level. $z$-statistics based on standard errors clustered at the firm level are reported in the parentheses. $* * *, * *$, and $*$ denote significant levels at $1 \%, 5 \%$, and $10 \%$, respectively.

\begin{tabular}{|c|c|c|}
\hline & \multicolumn{2}{|c|}{$P E R F \_T U R N O V E R_{i, t}$} \\
\hline & $\begin{array}{c}\text { Firm-Specific } Y 1 \\
(1)\end{array}$ & $\begin{array}{c}\text { CEO-Firm-Specific } Y 1 \\
(2)\end{array}$ \\
\hline$P E R F_{i, t}$ & $\begin{array}{c}-1.496 * * * \\
(-14.455)\end{array}$ & $\begin{array}{c}-1.338 * * * \\
(-11.978)\end{array}$ \\
\hline$P A S T_{-} P E R F_{i-1}$ & $\begin{array}{l}-0.168^{*} \\
(-1.872)\end{array}$ & $\begin{array}{c}-0.242 * * * \\
(-2.850)\end{array}$ \\
\hline$P E R F_{i, t} \times P A S T_{-} P E R F_{i-1}$ & $\begin{array}{c}-0.574 * * * \\
(-3.463)\end{array}$ & $\begin{array}{c}-0.828 * * * \\
(-3.824)\end{array}$ \\
\hline Year-Quarter Fixed Effects & Yes & Yes \\
\hline Firm and CEO Characteristics & Yes & Yes \\
\hline$N$ & 81,933 & 77,311 \\
\hline Pseudo $R$-squared & 0.032 & 0.029 \\
\hline
\end{tabular}




\section{Table A3}

Robustness to Including Industry Fixed Effects and Using Hazard Model with Stratification

In column (1), we show robustness to including industry fixed effects in our baseline specification. In column (2), we additionally use hazard regression with stratification by allowing baseline hazards (the hazard rates when subjects enter the study) to be different across year-quarters and industries to account for the likely time trends and industry patterns in the dependent variable.

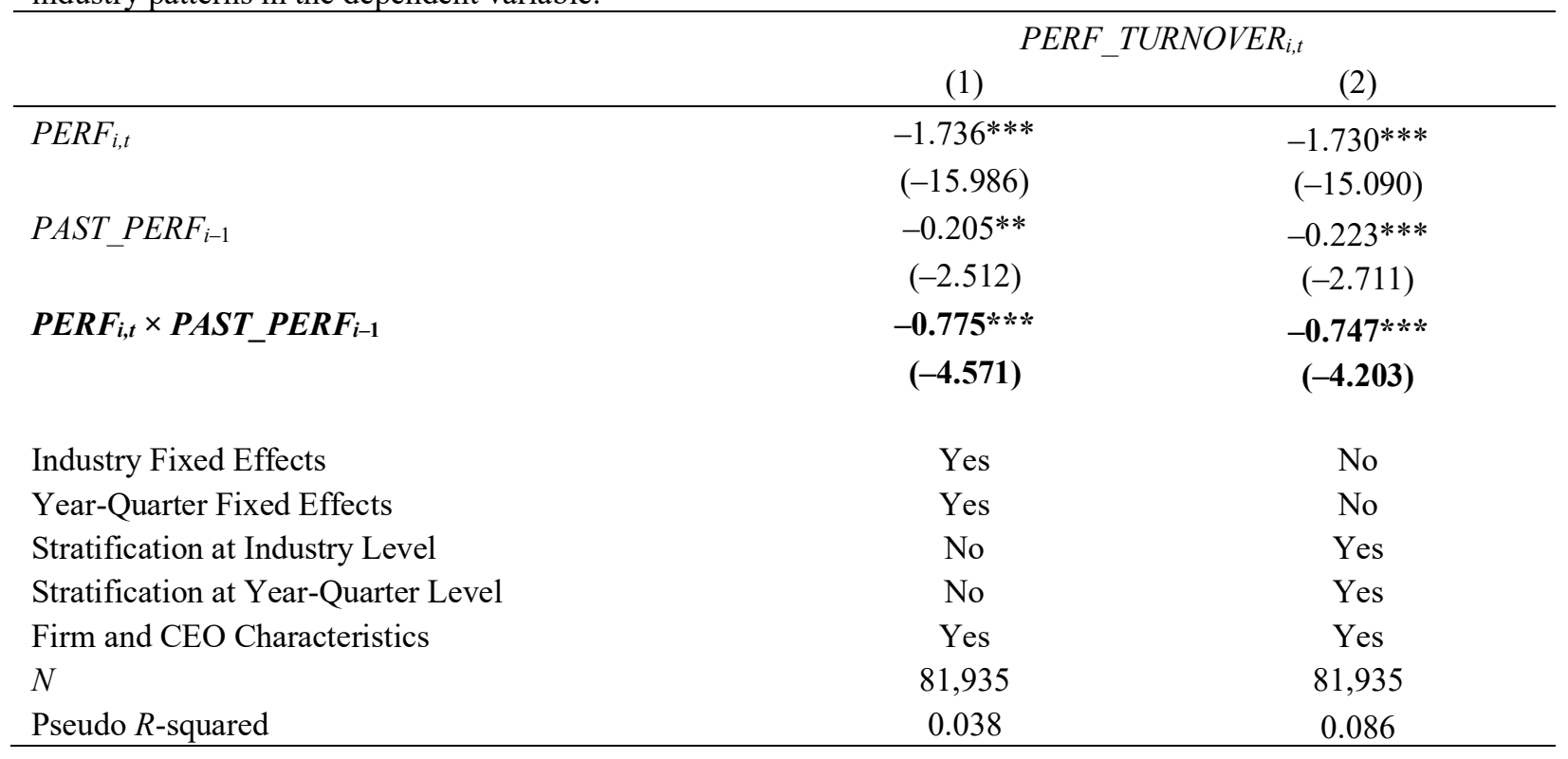

